\title{
Effects of phosphorus-mobilizing bacteria on tomato growth and soil microbial activity
}

\author{
Dinah Nassal - Marie Spohn • Namis Eltlbany • \\ Samuel Jacquiod • Kornelia Smalla • Sven Marhan • \\ Ellen Kandeler
}

Received: 30 March 2017 / Accepted: 7 December 2017 /Published online: 22 December 2017

(C) The Author(s) 2017. This article is an open access publication

\begin{abstract}
Aims The aim of our study was to clarify whether inoculating a soil with Pseudomonas sp. RU47 (RU47) bacteria would stimulate the enzymatic cleavage of organic $\mathrm{P}$ compounds in the rhizosphere and bulk soil, promoting plant growth. Adding either viable or heat treated RU47 cells made it possible to separate direct from indirect effects of the inoculum on $\mathrm{P}$ cycling in soil and plants.

Methods We performed a rhizobox experiment in the greenhouse with tomato plants (Solanum lycopersicum) under low P soil conditions. Three inoculation treatments were conducted, using unselectively grown soil bacteria (bacterial mix), heat treated (HT-RU47) and viable RU47 (RU47) cells, and one not inoculated,
\end{abstract}

Responsible Editor: Phil Haygarth.

Electronic supplementary material The online version of this article (https://doi.org/10.1007/s11104-017-3528-y) contains supplementary material, which is available to authorized users.

D. Nassal $(\bowtie) \cdot$ S. Marhan $\cdot$ E. Kandeler Institute of Soil Science and Land Evaluation, Soil Biology, University of Hohenheim, Stuttgart, Germanye-mail: dinah.nassal@gmail.com

\section{Spohn}

Department of Soil Ecology, Bayreuth Center of Ecology and Environmental Research (BayCEER), University of Bayreuth, Bayreuth, Germany

N. Eltlbany $\cdot$ K. Smalla

Institute for Epidemiology and Pathogen Diagnostics, Julius Kühn-Institute, Federal Research Centre for Cultivated Plants, Braunschweig, Germany optimally P-fertilized treatment. We verified plant growth, nutrient availability, enzyme activities and microbial community structure in soil.

Results A plant growth promotion effect with improved $\mathrm{P}$ uptake was observed in both RU47 treatments. Inoculations of RU47 cells increased microbial phosphatase activity (PA) in the rhizosphere.

Conclusions Plant growth promotion by RU47 cells is primarily associated with increased microbial PA in soil, while promotion of indigenous Pseudomonads as well as phytohormonal effects appear to be the dominant mechanisms when adding HT-RU47 cells. Thus, using RU47 offers a promising approach for more efficient $\mathrm{P}$ fertilization in agriculture.
N. Eltlbany Faculty of Agriculture, Suez Canal University, Ismailia, Egypt

S. Jacquiod Agroécologies UMR1347, INRA Dijon Center, Dijon, France 
Keywords Phosphorus-mobilizing bacteria . Phosphorus-solubilizing bacteria $\cdot$ Plant growthpromoting bacteria $\cdot$ Solanum lycopersicum .

Pseudomonas

\section{Introduction}

While it is well known that rhizosphere processes are important for plant $\mathrm{P}$ acquisition (Jones and Darrah 1994; Hinsinger 2001), the processes underlying growth promotion by beneficial microorganisms are not yet well understood. Since organic P is often the dominant form of P found in soils (Ron Vaz et al. 1993; Shand et al. 1994) and may constitute up to $90 \%$ of the total $P$ in soil (Khan et al. 2009), P mineralisation is a prerequisite to convert organic $\mathrm{P}$ into a plant available form. $\mathrm{P}$ mineralisation is catalysed by extracellular phosphatases produced by microorganisms and plants. While microorganisms produce both acid and alkaline phosphatases, plants produce only acid phosphatases (Dick et al. 1983; Juma and Tabatabai 1988; Nannipieri et al. 2011). Microbial and plant $P$ acquisition occur in different zones of the rhizosphere. Plant uptake of P occurs mostly at the root tip and in the proximal elongation zone, whereas microbial $\mathrm{P}$ uptake is highest in the root hair zone (Marschner et al. 2011). Using zymography in a rhizobox experiment, Spohn and Kuzyakov (2013) demonstrated the spatial separation of acid and alkaline phosphatase activity (PA) in the rhizosphere of lupines. While acid PA was associated with the root, alkaline PA was more widely distributed in the bulk soil (Spohn and Kuzyakov 2013; Spohn et al. 2013; Spohn et al. 2015; Hofmann et al. 2016). Microbial phosphatases comprise the major share of phosphatases in soil (Tabatabai 1994; Tarafdar et al. 2001), contributing significantly to the $P$ supply of plants (Frossard et al. 2000; Oehl et al. 2004). However, with respect to $\mathrm{P}$ foraging, the plant-microbial relationship can be competitive as well as mutualistic (Richardson et al. 2009). Hence, without phosphate fertilizers, P supply is generally not sufficient for effective crop production in most agricultural soils.

Phosphorus-mobilizing bacteria (PMB) are beneficial bacteria that effectively mobilize $\mathrm{P}$ through solubilization of sorbed P pools and mineralization of organic P compounds which are otherwise not readily available to the plant. Application of PMB to soils can therefore be a promising approach for improving $\mathrm{P}$ fertilization efficiency in agriculture. Plant growth-promoting effects resulting from targeted application of high-concentrations of PMB strains such as representatives from Bacillus, Pseudomonas, and Rhizobium in soils limited in P availability for plants have been documented in several studies (Chabot et al. 1996; Sundara et al. 2002; Kaur and Reddy 2014). Whether future use of PMB can improve $P$ nutrition of arable crops and vegetables remains to be tested. Three different microbial-driven functional mechanisms are currently being explored. First, added PMB may catalyze the hydrolysis of organic P compounds by the release of phosphatases (Tarafdar and Claassen 1988). Second, PMB may solubilize bound inorganic P into easily available phosphates by secreting organic acids which would reduce rhizosphere $\mathrm{pH}$. Organic acids as well as bicarbonates, carboxylates, and other anions biotically released may function as exchange ligands (Kpomblekou-a and Tabatabai 1994; Deubel et al. 2000; Jones 2011). Third, added PMB may interact synergistically with other beneficial indigenous microbes, like mycorrhizal fungi or $\mathrm{N}_{2}$ fixing bacteria optimizing P mobilization in soil (Belimov et al. 1995; Zaidi et al. 2003; Zhang et al. 2016). Although the role of PMB during P solubilization has been investigated (Kim et al. 1997; Khan et al. 2007; Fankem et al. 2008), the importance of enzymatic cleavage of organic $P$ resources by PMB, especially under P-limited conditions, has been less well studied. Kaur and Reddy (2014) demonstrated that enhanced wheat and maize growth after inoculation of an agricultural field with Pantoea cypripedii and Pseudomonas plecoglossicida was accompanied by an increase in phosphomonoesterase, phytase and dehydrogenase activities in soil. In addition, Eltlbany et al. (under review), conducted a pot experiment with tomato plants grown in soil with reduced $\mathrm{P}$ fertilization and found considerably enhanced plant growth following inoculation with Bacillus amyloliquefaciens FZB42 spores (RhizoVital@) as well as Pseudomonas sp. DSMZ 13134 (Proradix (®) or Pseudomonas sp. RU47. PA tended to increase in the rhizosphere; alkaline phosphomonoesterase with the addition of each of the two commercial products, and acid phosphomonoesterase with the addition of Pseudomonas sp. DSMZ 13134 and Pseudomonas sp. RU47. It is possible that the plant growth-promoting function of these three different bacterial strains is based mainly on their enhanced phosphatase production in the rhizosphere of plants. Since the formulation of the commercial products (i.e. the carrier matrix; culture media, skimmed milk powder, or gum arabic) may also affect microbial $\mathrm{P}$ mineralization, we selected Pseudomonas sp. RU47 (RU47) as the model organism, omitting any formulation. 
Whereas the addition of viable cells of RU47 should clarify direct mechanisms (e.g. enzyme production by the PMB), the addition of heat treated PMB strains should allow testing indirect mechanisms (e.g. via endogenous microorganisms). To exclude apparent plant growthpromoting effects of the PMB due to increased microbial activity by addition of living soil bacteria, an inoculation treatment using a mix of soil bacterial isolates was also evaluated. The following hypotheses were tested. (1) Added viable RU47 cells successfully colonize the soil and lead to a plant growth-promoting effect. (2) The plant growth-promoting effect of viable RU47 under P-deficient soil conditions is based on enhanced PA leading to enhanced $P$ availability in soil and increased uptake by plants. (3) Added viable RU47 dominates colonization of the rhizosphere, leading to spatially distinct zones of enriched alkaline/acid PA and to a shift in microbial community composition which were analyzed by illumina sequencing of 16S rRNA gene fragments amplified from total community DNA.

\section{Materials and methods}

\section{Rhizobox experiment}

The experiment was performed under low $\mathrm{P}$ availability soil conditions using Pseudomonas sp. RU47 (RU47) as the PMB, and tomato (Solanum lycopersicum L. var. Mobil) as the test plant. We established four treatments to account for the response of plants to heat treated (HT) or viable PMB as well as to account for the possible plant growth stimulation by $\mathrm{P}$ fertilization. To exclude apparent plant growth-promoting effects of the PMB due to increased microbial activity from having added living soil bacteria, which could affect the P efficiency of plants, a treatment was performed using unselectively cultivated soil bacteria for inoculation (bacterial mix). To verify the effects of HT and viable PMB on plant growth and nutrition, heat treated RU47 cells (HTRU47), and viable RU47 (RU47) were used for inoculation in two different treatments. In order to evaluate effects of $\mathrm{P}$ fertilization on plant growth, we conducted an optimally P-fertilized non-inoculation treatment (Pfertilized). Details of microorganism cultivation and inoculation are described in 2.2. Although the study aimed to determine the effects of PMB under low plant available $\mathrm{P}$ soil conditions, in order to achieve successful germination, a slight $\mathrm{P}$ fertilization of $50 \mathrm{mg} \mathrm{kg}-1$ was applied to all treatments, excluding the optimally Pfertilized $\left(200 \mathrm{mg} \mathrm{kg}^{-1}\right)$ non-inoculation treatment. Hence, the experiment consisted of four treatments, with four replicates per treatment. Tomato plants were grown in rhizoboxes with inner dimensions of $28.0 \mathrm{~cm} \times$ $4.5 \mathrm{~cm} \times 16.5 \mathrm{~cm}$, and filled with a soil substrate composed of Luvisol topsoil and quartz sand $(0.2-1.4 \mathrm{~mm})$ in a ratio of $1: 1(w / w)$. The Luvisol was considered as a heavy loam soil and had the following characteristics: pH $7.1\left(\mathrm{CaCl}_{2}\right), 26.2 \%$ sand, $52.2 \%$ silt, $21.6 \%$ clay, $2.3 \%$ total $\mathrm{C}, 2.0 \%$ organic $\mathrm{C}, 1.8 \mathrm{mg} \mathrm{NH}_{4}{ }^{+} \mathrm{kg}^{-1}$, $53.0 \mathrm{mg} \mathrm{NO}_{3}{ }^{-} \mathrm{kg}^{-1}$ and $24.1 \mathrm{mg} \mathrm{P}$ (Olsen) $\mathrm{kg}^{-1}$. The soil, selected on the basis of its low concentration of plant available $\mathrm{P}$ (calcium lactate extraction of $20 \mathrm{mg}$ $\mathrm{kg}^{-1}$ ), was taken from an unfertilized grassland located on the campus of the University of Hohenheim (Stuttgart, Germany). Each rhizobox was filled with $1918.0 \mathrm{~g}$ dry matter $(\mathrm{DM})$ of sieved $(<5 \mathrm{~mm})$ soil substrate. Before sowing, the soil substrate was optimally fertilized with respect to $\mathrm{N}$ (100 $\left.\mathrm{mg} \mathrm{kg}^{-1}\right), \mathrm{K}$ (150 mg $\mathrm{kg}^{-1}$ ) and $\mathrm{Mg}$ (50 $\mathrm{mg} \mathrm{kg}^{-1}$ ) and adjusted to a water holding capacity of $50 \%$. Three tomato seeds were sown at a depth of 1-2 cm directly into each rhizobox and thinned to one plant per rhizobox after germination. In order to promote root growth along the hinged wall, rhizoboxes were placed at a $50^{\circ}$ inclination. To avoid light-derived influences on root growth and behaviour, all boxes were wrapped in aluminium foil. The experiment was conducted for 39 days under greenhouse conditions. Rhizoboxes were distributed randomly and placed on wooden planks to exclude contamination by leaking irrigation water. Plants were watered to maintain a water holding capacity of $50 \%$ until 25 days after sowing, with water content checked gravimetrically on a daily basis. Due to small loss of soil while conducting the soil in situ zymography (2.6), from 25 days after sowing each rhizobox was watered with the same volume of $20 \mathrm{~mL}$. This volume corresponded to the average volumes of water used for watering at 23 days after sowing; volumes were increased up to $35 \mathrm{~mL}$ when radiation and temperature have risen in the greenhouse. Watering was performed using deionized water $\left(\mathrm{H}_{2} \mathrm{O}_{\text {deion }}\right)$, applied in $5 \mathrm{~mL}$ steps to avoid leakage along rhizobox edges.

Microbial cultivation and inoculation

RU47 (Adesina et al. 2007) was cultured in King's B liquid medium (King et al. 1954) with $50 \mathrm{mg} \mathrm{L}^{-1}$ added 
rifampicin (resistance by spontaneous mutation) at $28.5{ }^{\circ} \mathrm{C}$ in an incubator shaker (SM 30 Control; Edmund Bühler, Hechingen, Germany) for $24 \mathrm{~h}$; cultivation vessels were wrapped in aluminium foil to protect the antibiotic from light. We modified the growth conditions of Pseudomonas described by Xue et al. (2013) to maintain the exponential growing phase (to ensure inoculation by viable cells) and to have greater time flexibility during inoculation preparation. Briefly, we followed the following protocol: Bacterial mixes were grown in glucose-enriched $\left(2 \mathrm{~g} \mathrm{~L}^{-1}\right)$ LB-Lennox liquid medium (Bertani 1951; Lennox 1955) at $28.5^{\circ} \mathrm{C}$ for $24 \mathrm{~h}$ (incubator shaker) using a sample of the untreated soil as the inoculum. Glucose enrichment was chosen in order to avoid $\mathrm{C}$ limitation of bacterial growth. After incubation, all cultures were centrifuged $\left(4700 \mathrm{~g} \mathrm{~min}^{-1}\right)$ for $10 \mathrm{~min}$. Pellets were washed twice in sterile $0.3 \% \mathrm{NaCl}$ solution and resuspended in sterile $0.3 \% \mathrm{NaCl}$ solution. In the treatments using the bacterial mix, remaining soil components were removed by trapping on folded filter paper (grade 4) before cell washing. Cell suspensions were photometrically measured (BioPhotometer, Eppendorf, Germany) and adjusted to an $\mathrm{OD}_{600}=1.0$ corresponding to a cell density of approximately $10^{9}$ cells $\mathrm{mL}^{-1}$, as described in Xue et al. (2013). However, overestimates of cell density resulting from soil-derived turbid material remaining in cell suspensions containing bacterial isolates cannot be fully excluded. The killing of RU47 cells, which were used in one of the treatments, was performed as follows: bacterial suspension $\left(\mathrm{OD}_{600}=1.0\right)$ was placed in a sterile Erlenmeyer flask and boiled for $1 \mathrm{~min}$ on a heating plate. To minimize volume loss, the flask was covered and cooled to room temperature to exclude volume error before being used for inoculation. Pre-tests confirmed that this procedure was sufficient to kill RU47 cells, as plating exhibited no growth of RU47.

Plants were inoculated three times, each with a cell density of $10^{9}$ cells $\mathrm{mL}^{-1}\left(\mathrm{OD}_{600}=1.0\right)$. The first inoculation was conducted by seed coating. Under gentle and continuous vortexing, $5 \mu \mathrm{L}$ of cell suspension was successively added to five tomato seeds. The volume required for entire seed coating had been tested with ink (Pelikan, Pottendorf, Austria) before starting the experiment. To prevent drying of the inoculant, coated seeds initially remained in the closed Falcon tubes, which were used performing the seed coating, and were immediately sown (i.e. within less than $5 \mathrm{~min}$ ). Success of seed coating (i.e. viability and cell concentration of
RU47) was controlled by using three of the inoculated seeds followed by washing with $1 \mathrm{~mL}$ sterile $0.3 \% \mathrm{NaCl}$ solution and plating $100 \mu \mathrm{L}$ of the suspension on King's B-Agar medium ( $50 \mathrm{mg}$ rifampicin $\mathrm{L}^{-1}$ ) in three dilution stages. Plates were incubated at $28.5^{\circ} \mathrm{C}$ until growing colonies were unequivocally countable on the agar (after approximately $36 \mathrm{~h}$ ). The second inoculation was applied directly after seed germination, and the last inoculation was applied one week later. Both inoculations were performed with $6 \mathrm{~mL} \mathrm{~kg}^{-1}$ soil substrate DM, directly applied to the soil surface to simulate farm practice. To avoid a watering effect, the P-fertilized non-inoculation treatment was inoculated with $0.3 \%$ $\mathrm{NaCl}$ solution with corresponding volumes per inoculation. Viability and unviability of the RU47 cells used as well as sterility of the $0.3 \% \mathrm{NaCl}$ solution were checked by plating and subsequent incubation at $28.5^{\circ} \mathrm{C}$ for $48 \mathrm{~h}$ after every inoculation.

\section{Plant properties}

\section{Plant analyses during the growth period}

Stem diameter, leaf number and area, shoot height and $\mathrm{P}$ deficiency symptoms were recorded at temporal intervals of minimum 2 and maximum 4 days, starting 20 days after sowing. While stem diameter and leaf area (length $\mathrm{x}$ width) were measured using a precision pocket vernier caliper (150 mm, Format, Wuppertal, Germany), shoot height, defined as the vertical length from stem base to youngest leaf's tip, was measured by a ruler. P deficiency symptoms were defined as the expression of violet discoloration on the undersides of leaves and determined as a percentage of total leaf area.

\section{Plant analyses after harvest}

Shoots of every replicate were separately and carefully cut from the soil surface using a sterilized (70\% ethanol) scalpel. Shoots were briefly rinsed with $\mathrm{H}_{2} \mathrm{O}_{\text {deion }}$ to remove adhering dust, then dried at $60{ }^{\circ} \mathrm{C}$ in separate aluminium trays for 3 days to estimate dry weight.

Determination of plant biomass $\mathrm{P}$ in tomato shoots was performed by sequential microwave digestion based on Kalra et al. (1989) followed by photometric measurement of molybdenum blue. Ground samples were transferred into Teflon containers to which $1 \mathrm{~mL}$ $\mathrm{H}_{2} \mathrm{O}_{\text {deion }}, 2.5 \mathrm{~mL} \mathrm{HNO}_{3}$ and $2 \mathrm{~mL} \mathrm{H}_{2} \mathrm{O}_{2}$ were added. After soaking for $1 \mathrm{~h}$, samples were incinerated at $70^{\circ} \mathrm{C}$ 
(3 min) and $210{ }^{\circ} \mathrm{C}(62 \mathrm{~min})$ at $1400 \mathrm{~W}$, using an ETHOSlab microwave (MLS, Leutkirch, Germany). The diluted $\left(1: 1 \mathrm{H}_{2} \mathrm{O}_{\text {deion }}\right)$ and filtered (blue ribbon filter) suspensions were photometrically measured after a dilution of 1:3 $\mathrm{H}_{2} \mathrm{O}_{\text {deion }}$ using Murphy and Riley color reagent (Murphy and Riley 1962) at $710 \mathrm{~nm}$ in a microplate absorption reader (ELx808; BioTek Instruments Inc., Winooski, VT, USA).

Soil sampling

Rhizosphere and bulk soil samples were immediately put on ice for short-term storage. While DNA was directly extracted from the rhizosphere soils (see 2.5), bulk soil samples were sieved $(<2 \mathrm{~mm})$, after which aliquots of each replicate were frozen at $-20{ }^{\circ} \mathrm{C}$ until analyses.

Tracing RU47 and analyses of microbial community composition

\section{DNA extraction}

DNA was extracted according to Schreiter et al. (2014b) with some modifications. Briefly, after removing loosely adhering soil by vigorously shaking the roots, the complete root systems of one replicate per treatment were combined, then cut into pieces of approximately $1 \mathrm{~cm}$ length and carefully mixed. Five $g$ of cut roots with tightly adhering soil were transferred to a Stomacher bag, homogenized in a Stomacher 400 Circulator (Seward Ltd., Worthing, UK) for $1 \mathrm{~min}$ at high speed after adding $15 \mathrm{~mL}$ sterile $0.3 \%$ $\mathrm{NaCl}$; supernatant was then collected in a Falcon tube. This step (same $5 \mathrm{~g}$ of root material) was repeated twice, the combined supernatants $(45 \mathrm{~mL})$ of three Stomacher homogenizations were centrifuged at $10,000 \mathrm{~g}$ for $15 \mathrm{~min}$, after which pellets were frozen and stored at $-20{ }^{\circ} \mathrm{C}$. The use of Stomacher method to detach microbial cells adhering to root and rhizosphere does not fully exclude a coextraction of plant cells; however, pre-tests of this method revealed only minor contaminations with plant DNA. Total community DNA (TC-DNA) was extracted from $0.5 \mathrm{~g}$ of rhizosphere pellets using the Fast DNA SPIN Kit for Soil® (MP Biomedicals, Heidelberg, Germany) after a harsh lysis step as described by the manufacturer. The TC-DNA was purified with GENE CLEAN SPIN Kit ${ }^{\circledR}$ (MP Biomedicals, Heidelberg, Germany) according to the manufacturer's instructions and diluted 1:10 with $10 \mathrm{mM}$ Tris $\mathrm{HCl}, \mathrm{pH} \mathrm{8.0,} \mathrm{before} \mathrm{use.}$
Amplicon sequencing of $16 S$ rRNA gene amplicon from TC-DNA

Detailed procedure describing amplification of $16 \mathrm{~S}$ rRNA genes, sequencing, quality trimming and annotation was described previously (Nunes et al. 2016), respecting best practices guide lines (Schöler et al. 2017). Briefly, the $\sim 460$-bp fragment covering hypervariable regions V3-V4 of the small ribosomal subunit gene was amplified, tagged and sequenced using $2 \times 250 \mathrm{bp}$ paired-end high-throughput sequencing using illumina miseq Reagent Kits version 2 and Illumina ${ }^{\circledR}$ MiSeq ${ }^{\circledR}$ platform (Illumina, San Diego, CA, USA). Four biological replicates were sequenced for each of the four conditions tested, namely P-fertilized, bacterial mix, HT-RU47, RU47 (Table 1). Since no alpha-diversity estimation is performed in this study, the raw count data was used with appropriated biostatistic procedures accounting for uneven sequencing depth (Fig. S1) to avoid loss of information problems arising from rarefaction (McMurdie and Holmes 2014). A redundancy analysis (RDA) was performed on the profiles after relative abundance and $\log 10$ transformation to account for uneven sequencing depth and disparities between abundant and rare species using previously described methodology (Nunes et al. 2016). Major phylogenetic changes were detected at the phylum and class levels by means of ANOVA with a false discovery rate correction test (FDR, $p<0.05$ ). Operational taxonomic units (OTUs) responding significantly across experimental design were extracted using previously described methodology (Jacquiod et al. 2017) using an analysis of deviance (AOD) after generalized linear modelling (GLM) of the raw counts using negative binomial distribution (nb) with 1000 resampling iterations with residual variance, using the package mvabund (nbGLM, likelihood ratio test, $p<0.05$, Wang et al. 2012). This method was recently suggested as one of the most accurate way to extract significantly responding OTUs by minimizing the risk of error (Thorsen et al. 2016). A generalized heatmap of dominant (relative abundance $>0.1 \%$ ) and significantly responding OTUs was generated using previously described methodology (Jacquiod et al. 2016). A supporting table with the relative abundance of dominant Pseudomonas OTUs found in this study is provided in (Table S1). Sequencing fastq files were deposited in the Sequence read Archive (SRA) under the accession number SRP125744 (BioProject: PRJNA420007). 
Table 1 List and description of 16S rRNA gene amplicon sequencing samples generated in this study

\begin{tabular}{|c|c|c|c|c|}
\hline Name & Code & Description & Replicate & Sequences \\
\hline P-fertilized_a & $\mathrm{PC} 1$ & P-fertilized, non-inoculation & $\mathrm{R} 1$ & 27,143 \\
\hline P-fertilized_b & $\mathrm{PC} 2$ & P-fertilized, non-inoculation & $\mathrm{R} 2$ & 23,947 \\
\hline P-fertilized_c & PC3 & P-fertilized, non-inoculation & R3 & 36,680 \\
\hline P-fertilized_d & PC4 & P-fertilized, non-inoculation & $\mathrm{R} 4$ & 30,721 \\
\hline Bacterial mix_a & BM1 & Bacterial mix & $\mathrm{R} 1$ & 10,090 \\
\hline Bacterial mix_b & BM2 & Bacterial mix & $\mathrm{R} 2$ & 16,727 \\
\hline Bacterial mix_c & BM3 & Bacterial mix & $\mathrm{R} 3$ & 20,614 \\
\hline Bacterial mix_d & BM4 & Bacterial mix & R4 & 21,026 \\
\hline HT-RU47_a & HT1 & Heat treated Pseudomonas sp. RU47 & $\mathrm{R} 1$ & 20,787 \\
\hline HT-RU47_b & HT2 & Heat treated Pseudomonas sp. RU47 & $\mathrm{R} 2$ & 28,839 \\
\hline HT-RU47_c & HT3 & Heat treated Pseudomonas sp. RU47 & $\mathrm{R} 3$ & 26,321 \\
\hline HT-RU47_d & HT4 & Heat treated Pseudomonas sp. RU47 & R4 & 26,280 \\
\hline RU47_a & RU1 & Pseudomonas sp. RU47 & $\mathrm{R} 1$ & 10,493 \\
\hline RU47_b & RU2 & Pseudomonas sp. RU47 & $\mathrm{R} 2$ & 22,608 \\
\hline RU47_c & RU3 & Pseudomonas sp. RU47 & $\mathrm{R} 3$ & 23,818 \\
\hline RU47_d & RU4 & Pseudomonas sp. RU47 & $\mathrm{R} 4$ & 33,953 \\
\hline
\end{tabular}

\section{Phospholipid fatty acid (PLFA) analysis}

Microbial community structure was determined using PLFA profiles based on the alkaline methylation method of Frostegård et al. (1991). Lipid extraction and determination of fatty acid methyl esters (FAMEs) were performed according to Mackie et al. (2015). The divisions of PLFAs into bacteria and fungi were based on Frostegård and Bååth (1996), Zelles (1999) and Kandeler et al. (2008). Within bacteria, PLFAs were grouped into Gram-positive $\left(\mathrm{gram}^{+}\right)$, represented by i15:0, a15:0, i16:0, and Gram-negative (gram ${ }^{-}$), specified by cy 17:0 and cy19:0. Total bacterial PLFAs were calculated by the sum of gram $^{+}$and gram ${ }^{-}$plus $16: 1 \omega 7$. Fungal PLFA was represented by $18: 2 \omega 6,9$.

\section{Enzyme assays}

\section{Soil in situ zymography}

Soil in situ zymography uses membranes coated with methylumbelliferyl (MUF)-substrates which become fluorescent during enzyme cleavage, yielding information about the distribution of exoenzymes in soil. Distributions of alkaline and acid phosphomonoesterase (EC 3.1.3) in the rhizosphere were analysed by soil in situ zymography using an approach similar to that described in
Spohn and Kuzyakov (2014). All replicates were analysed by zymography at intervals of seven days, starting 18 days after sowing. MUF phosphate (4-MUF, Sigma-Aldrich, St. Louis, USA) was used as substrate; a $12 \mathrm{mM}$ solution was prepared and used to coat polyamide membranes, with diameter $14.2 \mathrm{~cm}$, and pore size $0.45 \mu \mathrm{m}$ (Sartorius, Göttingen, Germany). Substrate solution was prepared using modified universal buffer (MUB) adjusted to pH 11 for alkaline PA, and pH 6.5 for acid PA. Coated membranes were laid flat onto opened rhizoboxes which were separated from soil particles by an underlying layer of fresh $1 \%$ agarose gel ( $1 \mathrm{~mm}$ thick). Soil zymography was performed for each enzyme separately on the same rhizobox; first, acid PA was evaluated due to its affinity with the soil's $\mathrm{pH}$ of 7.4; second, alkaline PA was assayed. This order was maintained throughout the experiment. The possible loss of alkaline phosphatases by diffusion into the agarose gel or membrane during measurement of the acid PA cannot be excluded. In contrast to Spohn and Kuzyakov (2014), an incubation time of 35 min, adjusted to achieve the best practical contrast obtained by imaging, was used. Incubations were performed at a constant temperature of $20^{\circ} \mathrm{C}$; membranes were covered by aluminium foil to minimize liquid loss during incubation time. After incubation, membranes were placed on an epi-UV-desk (Desaga, Sarstedt, Nümbrecht, Germany) in the dark, and viewed at $360 \mathrm{~nm}$ wavelength. After being photographed 
with a digital camera (D60, Nikon, Tokyo, Japan) image processing and analysis of the zymograms were done using the open source software ImageJ. Digital images were transformed to 8-bit and multiplied by a factor of 1.25 to enhance the contrast. Images were transformed into false colors to create a color representation of enzyme activity, as given in Fig. S2. Calculation of enzyme activity was based on a linear function using a calibration curve fitted to different concentrations of 4-methylumbelliferone $(0,35,70,130,200,240 \mu \mathrm{M})$. Image processing of calibration zymograms was adapted to the modifications made with the soil zymograms. Calculation of enzyme activity was based on mean gray values obtained for each concentration in the calibration curve. As there was no distinct separation observed in enzyme activity between root and surrounding soil, the mean activity of the total incubated area was calculated.

\section{Analyses of enzyme activities in bulk after final harvest}

In addition to regularly conducted soil in situ zymography during the growth period, samples from the harvested bulk soil were analysed for potential alkaline and acid phosphatase (EC 3.1.3) activity using MUF substrates (4-MUF; SigmaAldrich, St. Louis, USA) according to Marx et al. (2001). The assay followed the method described in Poll et al. (2006) with an alteration; MUB instead of 2-(Nmorpholino)ethanesulfonic acid (MES) was used to ensure comparability with the results obtained by the zymograms. Alkaline phosphatase was measured at $\mathrm{pH} \mathrm{11,} \mathrm{acid} \mathrm{phos-}$ phatase at $\mathrm{pH}$ 6.5. Contrary to the findings of Niemi and Vepsäläinen (2005), pre-tests of this study demonstrated that the stability of 4-MUF phosphate in alkaline $\mathrm{pH}$ ranges ( $\mathrm{pH} 8-12)$ is constant over time ( $2 \mathrm{~h})$ when MUB instead of MES buffer is used. The activities of three enzymes involved in the $\mathrm{C}$ and $\mathrm{N}$ cycle were also measured using fluorescent MUF substrates (4-MUF; SigmaAldrich, St. Louis, USA): $\beta$-d-glucosidase (EC 3.2.1.21), $\beta$-xylosidase (EC 3.2.1.37) and $\beta$-N-acetylglucosaminidase (EC 3.2.1.52) according to Marx et al. (2001). Enzyme activity was measured in autoclaved MES buffer (pH 6.1).

\section{Microbial-bound $\mathrm{C}$ and $\mathrm{P}$}

To determine microbial biomass $\mathrm{C}\left(\mathrm{C}_{\mathrm{mic}}\right)$ the chloroform fumigation extraction method (Vance et al. 1987) according to Mackie et al. (2015) was used. $\mathrm{C}_{\text {mic }}$ was calculated using $\mathrm{keC} 0.45$ as extraction factor (Joergensen 1996). The estimation of microbial biomass $\mathrm{P}\left(\mathrm{P}_{\mathrm{mic}}\right)$ was done by liquid fumigation extraction with anion-exchange resin membranes (Kouno et al. 2002) using hexanol instead of liquid chloroform (Bünemann et al. 2004). A fresh weight of soil corresponding to $2 \mathrm{~g}$ dry matter was used for fumigated and non-fumigated subsamples of each sample. Pre-tests of this study indicated that the observed variability in $\mathrm{P}$ adsorption behaviour of soil depended on total $\mathrm{P}$ concentration in the soil solution to be analysed. Thus, the use of identical soil weights in all subsamples is a prerequisite to obtain an accurate correction factor for $\mathrm{P}$ retained by soil after fumigation. Fumigation and extraction were performed according to Bünemann et al. (2004). Extracted P was mixed with Murphy and Riley color reagent (Murphy and Riley 1962) and $\mathrm{H}_{2} \mathrm{O}_{\text {deion }}$ in a ratio of 1:1:4 (v/v), respectively. $\mathrm{P}$ concentration was photometrically measured at $710 \mathrm{~nm}$ using a microplate absorption reader (ELx808; BioTek Instruments Inc., Winooski, VT, USA). To determine the amount of $\mathrm{P}$ retained by soil particles and complexation after fumigation incubation, a defined $\mathrm{P}$ concentration $\left(\mathrm{K}_{2} \mathrm{HPO}_{4}\right)$, which was equal to the measured $\mathrm{P}$ concentrations in fumigated subsamples $\left(\mu \mathrm{g} \mathrm{P} \mathrm{g}^{-1}\right.$ ) was added to additional non-fumigated but otherwise identically treated subsamples. The ratio of recovered $\mathrm{P}$ to added $\mathrm{P}$ was used to calculate the $\mathrm{P}_{\text {mic }}$ concentration as follows:

$\mathrm{P}_{\text {mic }}\left[\mu \mathrm{g} \mathrm{g}^{-1}\right]=\frac{\left(\mathrm{P}_{\text {fumigated }}\left[\mu \mathrm{g} \mathrm{g}^{-1}\right]-\mathrm{P}_{\text {non-fumigated }}\left[\mu \mathrm{g} \mathrm{g}^{-1}\right]\right)}{\left(\mathrm{P}_{\text {recovered }}\left[\mu \mathrm{g} \mathrm{g}^{-1}\right] / \mathrm{P}_{\text {added }}\left[\mu \mathrm{g} \mathrm{g}^{-1}\right]\right)}$

Given values of water-extractable soil $\mathrm{P}\left(\mathrm{P}_{\mathrm{H} 2 \mathrm{O}}\right)$ corresponds to the $\mathrm{P}$ concentration $\left(\mu \mathrm{g} \mathrm{P} \mathrm{g}^{-1}\right)$ determined in the non-fumigated subsamples. However, as the used anion-exchange resin membranes compete for P adsorption by soil particles, it cannot be assumed that given $\mathrm{P}_{\mathrm{H} 2 \mathrm{O}}$ values completely represent the plant available $\mathrm{P}$ fraction.

\section{Mineral N}

To determine the concentrations of ammonium $\left(\mathrm{NH}_{4}{ }^{+}\right)$and nitrate $\left(\mathrm{NO}_{3}{ }^{-}\right)$in soil, undiluted (0.5 $\left.\mathrm{M} \mathrm{K}_{2} \mathrm{SO}_{4}\right)$ soil extracts from non-fumigated samples used for $\mathrm{C}_{\text {mic }}$ determination were colorimetrically measured on an Autoanalyzer III (Bran + Luebbe, Norderstedt, Germany). 
Statistical analyses

Differences between the treatments were statistically analysed as follows: Homogeneity of variance was tested by the Levene-test. Significance of differences was tested by ANOVA followed by the Tukey HSD-test, where $p<0.05$ was considered as the threshold value for significance. In cases of variance heterogeneity, the Games-Howell-test was used for pairwise comparison, where $p<0.05$ was also considered as significant. Statistical analyses were performed using SPSS Statistics 22 (IBM 2013).

\section{Results}

Plant growth and soil nutrients

In comparison to the bacterial mix treatment, inoculations with RU47 or HT-RU47 cells resulted in significantly enhanced plant growth, as shown by higher stem diameter, leaf number (Table 2), and shoot biomass (Fig. 1). Furthermore, we observed trends of increased shoot height and leaf area (Table 2). Symptoms of $\mathrm{P}$ deficiency (violet discoloration on the leaves) were less obvious in plants receiving both RU47 treatments than in the bacterial mix treatment but were not significantly different from the bacterial mix (Table 2). In comparison with the bacterial mix treatment, both RU47 treatments revealed higher P uptakes (Fig. 1). Plants of the treatments P-fertilized, and bacterial mix had concentrations of about $4 \mathrm{~g} \mathrm{P} \mathrm{kg}^{-1}$, which represented an adequate $\mathrm{P}$ supply for tomato plants before flowering. Plants inoculated with HT-RU47 cells had an optimal concentration of $6 \mathrm{~g} \mathrm{P} \mathrm{kg}^{-1}$, whereas plants inoculated with RU47 exhibited a remarkably low $P$ tissue concentration of $2 \mathrm{~g}$ $\mathrm{P} \mathrm{kg}^{-1}$ but this was an improvement in absolute uptake compared to the bacterial mix (Fig. 1, Table S2). In measurements of water-extractable $\mathrm{P}\left(\mathrm{P}_{\mathrm{H} 2 \mathrm{O}}\right)$ in soil, bulk soil samples of both RU47 treatments had a 2.3-fold higher $\mathrm{P}$ concentration than samples inoculated with the bacterial mix, and about one fourth of the P concentration measured in the optimally P-fertilized non-inoculation treatment (Table 2). No significant treatment effects on $\mathrm{NH}_{4}{ }^{+}$and $\mathrm{NO}_{3}{ }^{-}$concentrations in bulk soil were observed (Table 2). However, $\mathrm{NO}_{3}{ }^{-}$concentrations were negatively correlated with shoot biomass (Pearson's $r=-0.71 ; p<0.05$ ).
Enzyme activities involved in $\mathrm{P}, \mathrm{C}$, and $\mathrm{N}$ cycling

Soil in situ zymography has revealed that the addition of viable RU47 significantly increased alkaline PA in the rhizosphere of tomato on days 25-26 and 31-32 after sowing (Fig. 2a). Alkaline PA in the rhizosphere of plants inoculated with viable RU47 increased significantly over time, with highest activity on days 25-26 after sowing, whereas the temporal pattern was stable in the HT-RU47 treatment (Fig. 2a). Based on results found by zymography, the activity of acid phosphatase was marginally less than that detected for alkaline PA (Fig. 2a, b). Acid PA increased slightly over time; significant increases of $21 \%$ (bacterial mix) and $15 \%$ (RU47) could be observed in the treatments to which living bacteria were added (Fig. 2b). As expected, acid PA in the rhizosphere was positively correlated with plant properties (e.g. shoot height, Pearson's $r=0.60$; $p<0.001)$. Potential alkaline and acid PA in homogeneous bulk soil samples after final harvest indicated highest activities in both RU47 treatments (Table 2). RU47 inoculation did not influence enzyme activities involved in $\mathrm{C}$ and $\mathrm{N}$ cycling in bulk soil (Table 2). Nevertheless, the bacterial mix treatment stimulated activities of the mainly fungus-derived $\beta$-xylosidase by more than $100 \%$ compared with the average $\beta$ xylosidase activity observed in all other treatments (Table 2).

\section{Microbial biomass}

Both RU47 treatments did not influence microbial C content of the bulk soil (Fig. 3). Microbial biomass $\mathrm{P}$ was almost equal in all inoculation treatments and significantly higher than values detected in the P-fertilized treatment (Fig. 3). Thus the calculated atomic C:P ratio of 305 in microbial biomass of the P-fertilized treatment was much higher (4.4 times) as compared to the average C:P ratios of all other treatments (Table 2).

\section{PLFA}

The addition of RU47 did not result in significant shifts in microbial groups representation based on PLFA patterns (Table 2). However, while bulk soils of the Pfertilized and bacterial mix treatments exhibited identical PLFA patterns, abundances of bacterial PLFAs were higher in bulk soil inoculated with HT-RU47 or RU47 cells by 11 and 7\%, respectively (Table 2). Abundances 
Table 2 Summarized plant and soil properties of tomato plants under one optimally P-fertilized, non-inoculation (P-fertilized) and three inoculation treatments using unselectively cultivated soil bacteria (bacterial mix), heat treated RU47 (HT-RU47), or viable RU47 (RU47) cells, recorded 36 and 39 days after sowing (DAS)

\begin{tabular}{|c|c|c|c|c|c|}
\hline & & P-fertilized & Bacterial mix & HT-RU47 & RU47 \\
\hline & Unit & Mean & Mean & Mean & Mean \\
\hline \multicolumn{6}{|l|}{ Plant properties (36 DAS) } \\
\hline Shoot height & {$[\mathrm{cm}]$} & $33.8^{\mathrm{a}} \pm 0.6$ & $17.2^{b} \pm 2.8$ & $27.1^{\mathrm{a}} \pm 0.7$ & $26.4^{\mathrm{ab}} \pm 1.8$ \\
\hline Stem diameter & {$[\mathrm{cm}]$} & $0.5^{\mathrm{a}} \pm 0.0$ & $0.3^{\mathrm{b}} \pm 0.0$ & $0.5^{\mathrm{a}} \pm 0.0$ & $0.5^{\mathrm{a}} \pm 0.0$ \\
\hline Leaf number & - & $5.5^{\mathrm{a}} \pm 0.3$ & $3.3^{b} \pm 0.3$ & $5.0^{\mathrm{a}} \pm 0.0$ & $4.8^{\mathrm{a}} \pm 0.3$ \\
\hline Leaf area & {$\left[\mathrm{cm}^{2}\right]$} & $775.6^{\mathrm{a}} \pm 11.3$ & $205.4^{\mathrm{b}} \pm 84.2$ & $570.6^{\mathrm{ab}} \pm 34.8$ & $567.8^{\mathrm{ab}} \pm 101.7$ \\
\hline Violet discolouration & - & $0.0^{\mathrm{b}} \pm 0.0$ & $2.5^{\mathrm{a}} \pm 0.5$ & $0.8^{\mathrm{ab}} \pm 0.5$ & $1.0^{\mathrm{a}} \pm 0.0$ \\
\hline \multicolumn{6}{|l|}{ Soil properties (39 DAS) } \\
\hline $\mathrm{pH}\left(\mathrm{CaCl}_{2}\right)$ & - & $7.2^{b} \pm 0.0$ & $7.5^{\mathrm{a}} \pm 0.0$ & $7.5^{\mathrm{a}} \pm 0.0$ & $7.5^{\mathrm{a}} \pm 0.0$ \\
\hline $\mathrm{P}_{\mathrm{H} 2 \mathrm{O}}$ & {$\left[\mathrm{mg} \mathrm{kg}^{-1}\right]$} & $100.5^{\mathrm{a}} \pm 5.5$ & $9.6^{\mathrm{b}} \pm 5.1$ & $22.4^{\mathrm{b}} \pm 2.0$ & $22.6^{\mathrm{b}} \pm 1.0$ \\
\hline Molar microbial C:P ratio & - & $305.1 \pm 92.1$ & $55.1 \pm 16.1$ & $80.4 \pm 8.5$ & $73.7 \pm 7.2$ \\
\hline $\mathrm{NH}_{4}^{+}$ & {$\left[\mathrm{mg} \mathrm{kg}^{-1}\right]$} & $1.9 \pm 0.6$ & $2.1 \pm 0.4$ & $1.5 \pm 0.2$ & $1.1 \pm 0.1$ \\
\hline $\mathrm{NO}_{3}^{-}$ & {$\left[\mathrm{mg} \mathrm{kg}^{-1}\right]$} & $141.7 \pm 4.0$ & $159.5 \pm 3.5$ & $142.5 \pm 5.4$ & $150.6 \pm 4.5$ \\
\hline Gram $^{+}$PLFAs & {$\left[\right.$nmol FAME g $\left.{ }^{-1}\right]$} & $8.0 \pm 0.3$ & $8.0 \pm 0.2$ & $8.9 \pm 0.8$ & $8.6 \pm 0.3$ \\
\hline Gram $^{-}$PLFAs & {$\left[\mathrm{nmol} \mathrm{FAME} \mathrm{g}^{-1}\right]$} & $1.2 \pm 0.0$ & $1.2 \pm 0.0$ & $1.3 \pm 0.1$ & $1.3 \pm 0.1$ \\
\hline Bacterial PLFAs & {$\left[\mathrm{nmol} \mathrm{FAME} \mathrm{g}^{-1}\right]$} & $14.2 \pm 0.5$ & $14.2 \pm 0.3$ & $15.7 \pm 1.4$ & $15.2 \pm 0.6$ \\
\hline Fungal PLFA & {$\left[\mathrm{nmol}\right.$ FAME $\left.\mathrm{g}^{-1}\right]$} & $0.4 \pm 0.0$ & $0.4 \pm 0.0$ & $0.4 \pm 0.1$ & $0.4 \pm 0.0$ \\
\hline Acid phosphomonoesterase & {$\left[\mathrm{nmol} \mathrm{g}{ }^{-1} \mathrm{~h}^{-1}\right]$} & $73.8 \pm 20.1$ & $73.7 \pm 28.7$ & $105.5 \pm 10.3$ & $114.6 \pm 13.9$ \\
\hline Alkaline phosphomonoesterase & {$\left[\mathrm{nmol} \mathrm{g}^{-1} \mathrm{~h}^{-1}\right]$} & $475.9 \pm 33.5$ & $503.8 \pm 38.2$ & $518.5 \pm 31.1$ & $584.1 \pm 19.0$ \\
\hline ß-glucosidase & {$\left[\mathrm{nmol} \mathrm{g}^{-1} \mathrm{~h}^{-1}\right]$} & $188.7 \pm 10.5$ & $181.9 \pm 4.0$ & $187.5 \pm 12.6$ & $196.0 \pm 9.4$ \\
\hline $\mathrm{N}$-acetyl- $\beta$-glucosaminidase & {$\left[\mathrm{nmol} \mathrm{g}^{-1} \mathrm{~h}^{-1}\right]$} & $63.3 \pm 9.3$ & $45.1 \pm 3.9$ & $41.4 \pm 3.1$ & $43.4 \pm 1.6$ \\
\hline B-xylosidase & {$\left[\mathrm{nmol} \mathrm{g}^{-1} \mathrm{~h}^{-1}\right]$} & $13.2 \pm 3.2$ & $34.1 \pm 17.6$ & $17.9 \pm 1.3$ & $17.5 \pm 1.4$ \\
\hline
\end{tabular}

Values are presented as mean \pm standard error (SE) of four replicates. Significant differences (Tukey-HSD/Games-Howell, $p<0.05$ ) between the treatments are marked by lowercase letters. Please note the different time points of plant observation and soil sampling. Percentage of violet discolouration on the undersides of the leaves is based on total leaf area, coded as follows: $0 \%=0,>0-25 \%=1,>25-50 \%=2,>50-$ $75 \%=3,>75-100 \%=4$

of PLFAs representing gram ${ }^{+}$bacteria were higher by about $9 \%$ in treatments using both HT-RU47 and viable RU47 compared to the control and bacterial mix treatments (Table 2).

\section{Amplicon sequencing}

RDA demonstrated clear effect of RU47 inoculation along the first axis explaining about $24 \%$ of the variance, positively correlating with microbial biomass (total PLFA) and $\mathrm{PA}$, which, in turn were positively correlated with plant's $\mathrm{P}$ uptake, despite weak linkage to shoot biomass (Fig. 4). However, a negative correlation between RU47 and N pool in bulk soil was determined (Fig. 4). Second component clearly segregated clusters of the P-fertilized, noninoculation treatment from those of the bacterial mix treatment (about 19\% of the variance; Fig. 4). While OTU cluster of the P-fertilized treatment was positively correlated with plant's P uptake and shoot biomass, this treatment was mainly characterized by molar C:P ratio in microbial biomass as well as activities of soil enzymes involved in the $\mathrm{C}$ cycle $(\beta$-D-glucosidase, $\beta$-D-xylosidase; Fig. 4). Bacterial mix cluster showed highly positive correlation with the leaf discoloration, $\mathrm{N}$ pool, and $\mathrm{pH}$, while plant's $\mathrm{P}$ uptake, shoot biomass, and molar C:P ratio determined in bulk soil's microbial biomass were correlated negatively (Fig. 4).

Amplicon sequences provided insights into the phylogenetic composition of the prokaryotic community in tomato rhizosphere DNA of the four different treatments from plants sampled 39 days after sowing. In terms of alpha-diversity, a clear and significant differences 
Fig. 1 Tomato shoot biomass (dry weight) and plant-bound $\mathrm{P}$ of one optimally P-fertilized, noninoculation (P-fertilized) and three inoculation treatments using unselectively cultivated soil bacteria (bacterial mix), heat treated RU47 (HT-RU47), or viable RU47 (RU47) cells. Data were recorded 39 days after sowing. Error bars indicate standard error $(n=4)$; significant differences (Tukey-HSD, $p<0.05$ ) between the treatments are designated by lowercase letters

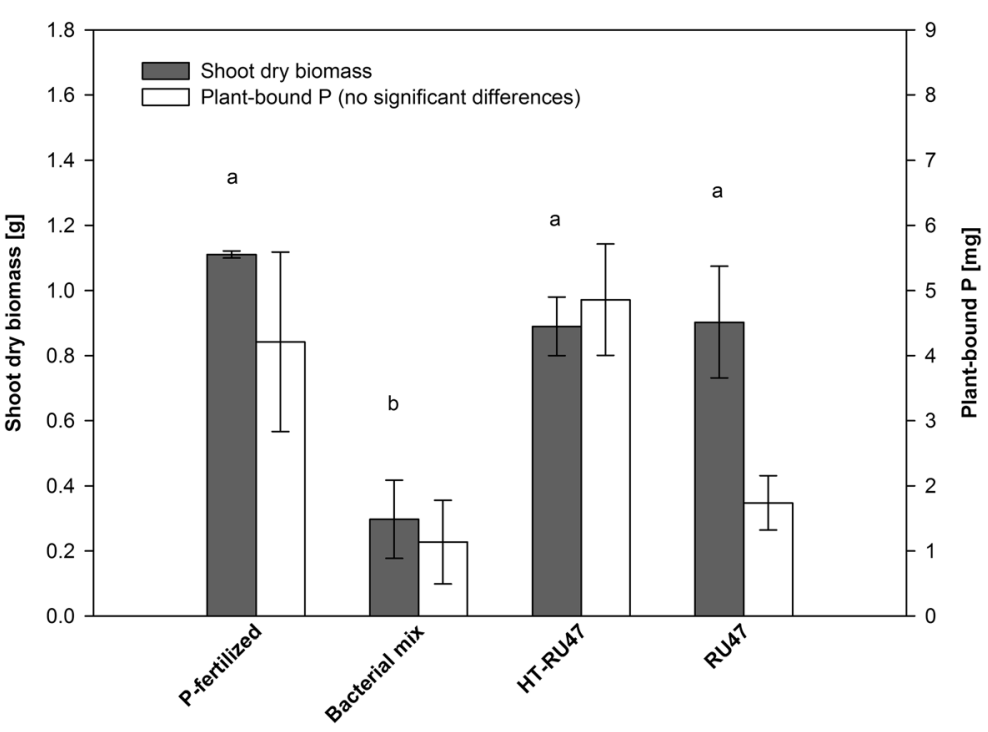

$(p<0.05)$ were observed between samples treated with dead/alive RU47 which had lower evenness (Shannon index: HT-RU47 $=3.66 \pm 0.34$ and RU47 $=3.89 \pm 0.10$ ) and richness (HT-RU47 $=649 \pm 72$ and RU47 $=683 \pm$ 46) as opposed to P-fertilized/bacterial mix samples (Shannon index: P-fertilized $=4.98 \pm 0.19$ and bacterial mix $=5.18 \pm 0.09$; Richness: P-fertilized $=884 \pm 21$ and Bacterial mix $=860 \pm 17$ ). The HT-RU47 and the RU47 treatments had significantly higher relative abundance of Proteobacteria. In particular Gammaproteobacteria were strikingly increased in relative abundance compared to the P-fertilized and bacterial mix treatments (Table 3). In both HT-RU47 and RU47 treatments Pseudomonas was significantly increased in relative abundance. Interestingly, in the HT-RU47 treatment the sequences were distinct from those related to RU47. Sequence comparison with the recently available RU47 genome sequence showed that two OTU were likely RU47 derived due to $16 \mathrm{~S}$ operon heterogeneities (Fig. S3). Although at the phylum level for Firmicutes there were no significant differences observed, the relative abundance of Bacilli was significantly lower in the HT-RU47 and RU47 treatments. Bacteroidetes (Cytophagia, Sphingobacteria) were significantly higher in the P-fertilized treatment. The less abundant phyla Gemmatimonadets, Nitrospirae, Chloroflexi, Planctomycetes and Verrucomicrobia had a significantly lower relative abundance in the HT-RU47 and the RU47 treatments compared to the P-fertilized and bacterial mix treatments (Table 3). Heatmap demonstrated that each treatment displayed distinct dominant OTUs significantly responding between treatments in term of abundance (Fig. 5). The heat map shows that RU47 related OTUs were dominant members of the tomato rhizosphere only in the RU47 treatment. Interestingly in the HT-RU47 treatments these OTU were not detected but instead OTU with sequence similarity to different Pseudomonas species were dominant. OTUs affiliated to Clostridium, Lysobacter and Tumebacillus showed a higher abundance in the bacterial mix treatments. Numerous dominant OTUs (18) were observed in the P-fertilized treatment that were affiliated to diverse range of genera belonging to different phyla (Fig. 5). Samples of the bacterial mix treatment had 4 OTUs with higher abundance, partly overlapping with those of the P-fertilized treatment, mostly belonging to Firmicutes and Gammaproteobacteria (Fig. 5). Furthermore, in RU47 treatment OTUs belonging to Rubrobacter sp. and Terrimonas sp. were found (Fig. 5).

\section{Discussion}

Plant growth

In tomato plants inoculated with RU47, not only stem diameter and leaf number, but also 3-fold higher shoot biomass was observed in comparison to plants which were inoculated with the bacterial mix (Table 2, Fig. 1). Therefore, the present study demonstrates the actual plant growth promoting activity of this particular inoculant, with similar results compared to previous studies. 
a

$18-19$

25-26

$31-32$

days after sowing
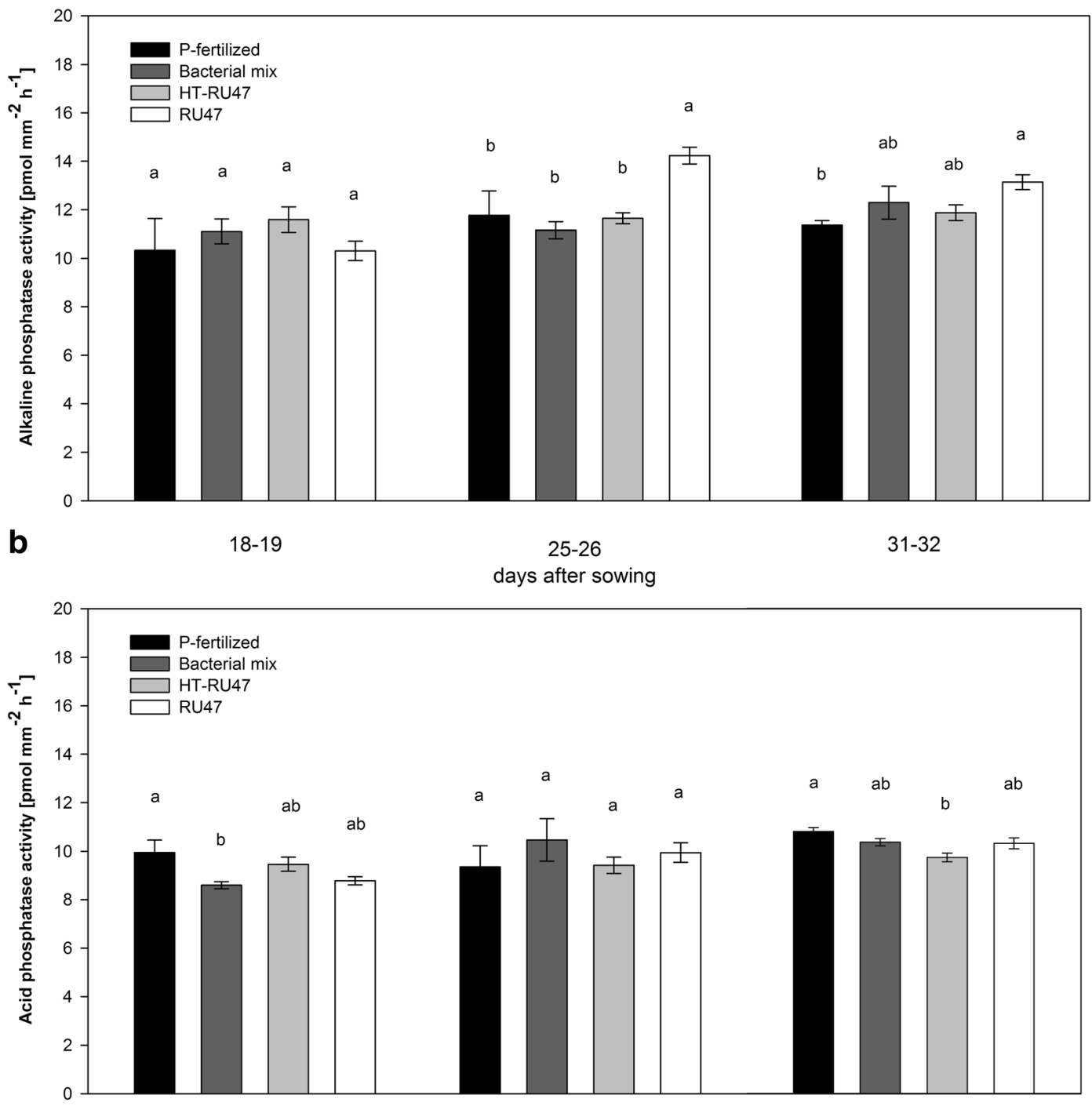

Fig. 2 a Alkaline phosphomonoesterase activity during different growth stages of tomato plants. The experiment comprised one optimally P-fertilized, non-inoculation (P-fertilized) and three inoculation treatments using unselectively cultivated soil bacteria (bacterial mix), heat treated RU47 (HT-RU47), or viable RU47 (RU47) cells. Error bars indicate standard error $(n=4)$. Letters indicate significant differences (Tukey-HSD, $p<0.05$ ) between the treatments, tested individually for each growth stage. b Acid

For instance, Kim et al. (1997) observed a 2-fold higher plant biomass in 35 day-old tomato plants inoculated with Enterobacter agglomerans cells compared to the not inoculated control. However, in our study, a growthpromoting effect was also observed in tomato plants inoculated with HT-RU47 cells (Fig. 1, Table 2). The difference between the treatments RU47 and HT-RU47 phosphomonoesterase activity during different growth stages of tomato plants. The experiment comprised one optimally P-fertilized, non-inoculation (P-fertilized) and three inoculation treatments using unselectively cultivated soil bacteria (bacterial mix), heat treated RU47 (HT-RU47), or viable RU47 (RU47) cells. Error bars indicate standard error $(n=4)$. Letters indicate significant differences (Tukey-HSD, $p<0.05$ ) between the treatments tested individually for each growth stage

makes it possible to estimate whether potential plant growth promotion is a result of direct or indirect mechanisms. Direct mechanisms can include, for example, the production of phosphatases by RU47 resulting in an improved supply of P by plants. Indirect mechanisms include the release of cell-derived phytohormones or other compounds which may stimulate and/or facilitate 
Fig. 3 Microbial-bound carbon $\left(\mathrm{C}_{\text {mic }}\right)$ and phosphorus $\left(\mathrm{P}_{\text {mic }}\right)$ in bulk soil of tomato plants harvested 39 days after sowing. The experiment comprised one optimally P-fertilized, noninoculation (P-fertilized) and three inoculation treatments using unselectively cultivated soil bacteria (bacterial mix), heat treated RU47 (HT-RU47), or viable RU47 (RU47) cells. Error bars indicate standard error $(\mathrm{n}=$ 4); significant differences (TukeyHSD, $p<0.05$ ) between the treatments are designated by lowercase letters

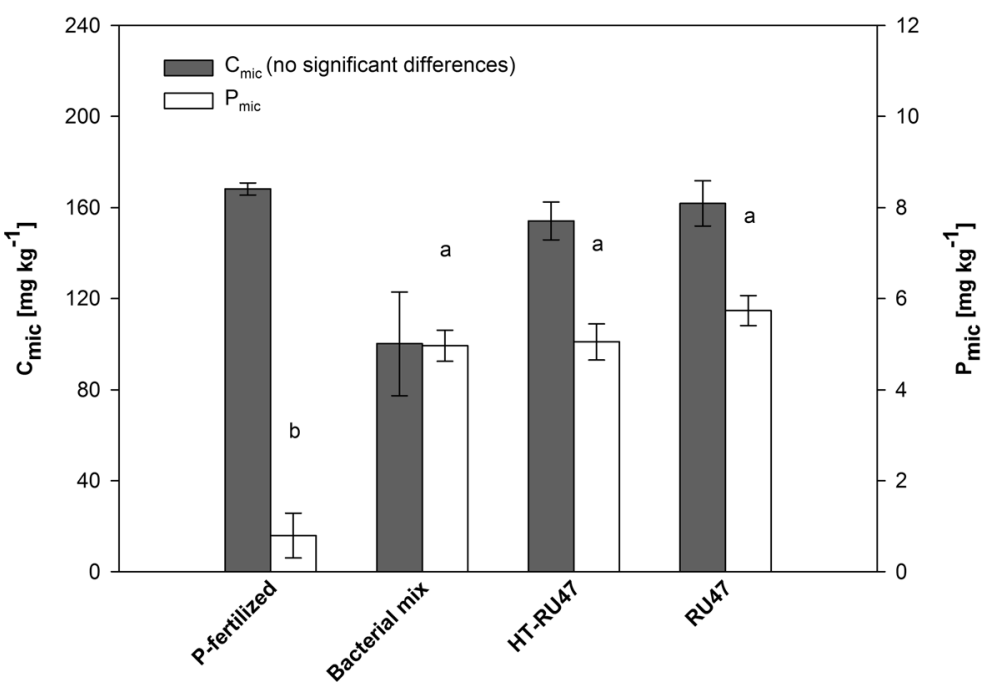

establishment of indigenous microbes and their activity in soil. These indirect mechanisms are discussed in more detail below.

\section{Tracing RU47}

The strain RU47 was originally isolated from a soil which had previously been reported as suppressive to phytopathogenic fungi (Adesina et al. 2007). Amplicon sequencing of 16S rRNA gene from TC-DNA, which was extracted from the rhizosphere, revealed clear taxonomic segregation between P-fertilized, bacterial mix, and both treatments where RU47 cells were added (Figs. 4 and 5, Table 3). Furthermore, as strain RU47 displays heterogeneity in its own $16 \mathrm{~S}$ sequence due to multiple genomic copies $(n=6)$, several OTUs were identified matching the RU47 variants (Fig. S3). Based on amplicon sequencing data cross-contaminations
Fig. 4 Redundancy analysis (RDA) applied on whole prokaryotic communities obtained from 16S amplicon sequencing in the rhizosphere of one optimally P-fertilized, noninoculation (P-fertilized) and three inoculation treatments using unselectively cultivated soil bacteria (bacterial mix), heat treated RU47 (HT-RU47), or viable RU47 (RU47) cells of tomato plants 39 days after sowing

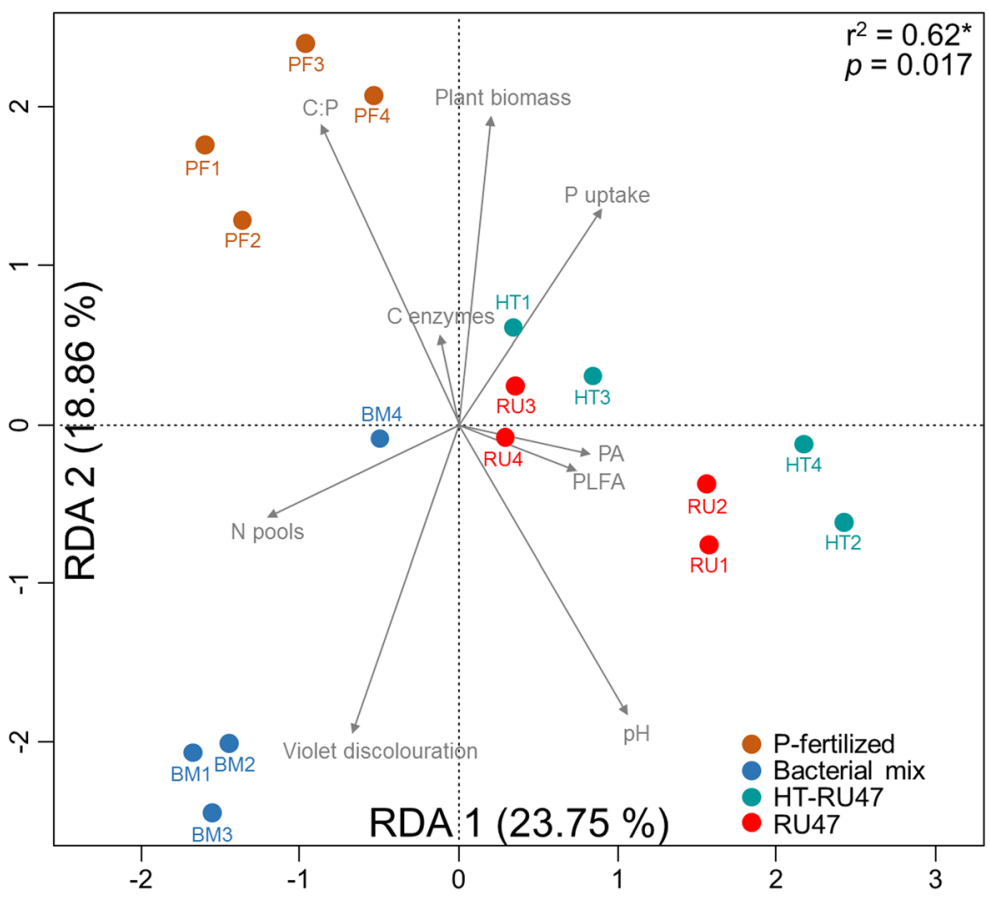


Table 3 Phylogenetic composition of the prokaryotic community in tomato rhizosphere DNA of one optimally P-fertilized, noninoculation (P-fertilized) and three inoculation treatments (bacterial mix of soil bacterial isolates; heat treated RU47 [HTRU47], or viable RU47 [RU47] cells) from plants harvested 39 days after sowing

\begin{tabular}{|c|c|c|c|c|}
\hline \multirow[b]{2}{*}{ Phylum/class } & P-fertilized & Bacterial mix & HT-RU47 & RU47 \\
\hline & Mean & Mean & Mean & Mean \\
\hline Proteobacteria & $40.7^{\mathrm{b}} \pm 4.4$ & $36.8^{\mathrm{b}} \pm 4.1$ & $62.4^{\mathrm{a}} \pm 5.6$ & $58.7^{\mathrm{a}} \pm 4.6$ \\
\hline Alphaproteobacteria & $8.8^{\mathrm{a}} \pm 0.6$ & $9.6^{\mathrm{a}} \pm 1.0$ & $4.0^{\mathrm{b}} \pm 0.9$ & $5.3^{\mathrm{b}} \pm 0.4$ \\
\hline Betaproteobacteria & $1.5^{\mathrm{a}} \pm 0.1$ & $1.1^{\mathrm{ab}} \pm 0.2$ & $1.2^{\mathrm{ab}} \pm 0.2$ & $0.9^{\mathrm{b}} \pm 0.1$ \\
\hline Deltaproteobacteria & $0.5^{\mathrm{a}} \pm 0.1$ & $0.4^{\mathrm{a}} \pm 0.1$ & $0.2^{\mathrm{b}} \pm 0.1$ & $0.2^{\mathrm{b}} \pm>0.01$ \\
\hline Gammaproteobacteria & $29.9^{\mathrm{b}} \pm 4.9$ & $25.6^{\mathrm{b}} \pm 4.8$ & $56.9^{\mathrm{a}} \pm 6.6$ & $52.4^{\mathrm{a}} \pm 4.1$ \\
\hline Unclassified & $>0.01 \pm>0.01$ & nd & $>0.01 \pm>0.01$ & nd \\
\hline Firmicutes & $26.7 \pm 3.3$ & $25.2 \pm 4.3$ & $19.2 \pm 3.0$ & $17.8 \pm 6.4$ \\
\hline Bacilli & $5.2^{\mathrm{a}} \pm 0.7$ & $3.9^{\mathrm{a}} \pm 0.7$ & $1.7^{\mathrm{b}} \pm 0.3$ & $1.7^{\mathrm{b}} \pm 0.2$ \\
\hline Clostridia & $21.5 \pm 3.4$ & $20.3 \pm 3.6$ & $18.0 \pm 3.0$ & $16.1 \pm 6.4$ \\
\hline Unclassified & $>0.01 \pm>0.01$ & $0.9 \pm 0.9$ & nd & nd \\
\hline Actinobacteria & $14.6^{\mathrm{b}} \pm 1.2$ & $22.9^{\mathrm{a}} \pm 2.0$ & $9.9^{\mathrm{c}} \pm 2.7$ & $14.9^{\mathrm{b}} \pm 0.9$ \\
\hline Bacteroidetes & $8.6^{\mathrm{a}} \pm 0.9$ & $4.0^{\mathrm{b}} \pm 0.3$ & $4.3^{\mathrm{b}} \pm 1.3$ & $4.3^{\mathrm{b}} \pm 0.6$ \\
\hline Bacteroidia & $1.2^{\mathrm{a}} \pm 0.2$ & $1.4^{\mathrm{a}} \pm 0.3$ & $0.6^{\mathrm{b}} \pm 0.1$ & $0.6^{\mathrm{b}} \pm 0.1$ \\
\hline Cytophagia & $0.4^{\mathrm{a}} \pm>0.01$ & $0.2^{\mathrm{b}} \pm 0.1$ & $0.2^{\mathrm{b}} \pm 0.1$ & $0.2^{\mathrm{b}} \pm>0.01$ \\
\hline Flavobacteriia & $0.6 \pm 0.1$ & $0.6 \pm 0.2$ & $0.5 \pm 0.2$ & $0.5 \pm 0.1$ \\
\hline Sphingobacteriia & $6.4^{\mathrm{a}} \pm 0.9$ & $1.8^{\mathrm{c}} \pm 0.4$ & $3.0^{\mathrm{bc}} \pm 0.9$ & $3.0^{\mathrm{b}} \pm 0.4$ \\
\hline Gemmatimonadetes & $3.3^{\mathrm{a}} \pm 0.5$ & $3.8^{\mathrm{a}} \pm 0.6$ & $1.2^{\mathrm{b}} \pm 0.4$ & $1.4^{\mathrm{b}} \pm 0.3$ \\
\hline Nitrospirae & $1.5^{\mathrm{a}} \pm 0.2$ & $1.9^{\mathrm{a}} \pm 0.3$ & $0.6^{\mathrm{b}} \pm 0.2$ & $0.8^{\mathrm{b}} \pm 0.1$ \\
\hline Chloroflexi & $1.4^{\mathrm{a}} \pm 0.2$ & $1.8^{\mathrm{a}} \pm 0.3$ & $0.5^{\mathrm{b}} \pm 0.2$ & $0.7^{\mathrm{b}} \pm 0.1$ \\
\hline Anaerolineae & $0.3^{\mathrm{a}} \pm 0.1$ & $0.4^{\mathrm{a}} \pm 0.1$ & $0.1^{\mathrm{b}} \pm>0.01$ & $0.2^{\mathrm{b}} \pm>0.01$ \\
\hline Caldilineae & $0.4^{\mathrm{a}} \pm 0.1$ & $0.5^{\mathrm{a}} \pm 0.1$ & $0.2^{\mathrm{b}} \pm>0.01$ & $0.2^{\mathrm{b}} \pm>0.01$ \\
\hline Chloroflexia & $0.2^{\mathrm{a}} \pm>0.01$ & $0.3^{\mathrm{a}} \pm 0.1$ & $0.1^{\mathrm{b}} \pm>0.01$ & $0.1^{\mathrm{b}} \pm>0.01$ \\
\hline Dehalococcoidia & $0.1 \pm>0.01$ & $0.1 \pm>0.01$ & $>0.01 \pm>0.01$ & $0.0 \pm>0.01$ \\
\hline Ktedonobacteria & $>0.01 \pm>0.01$ & nd & nd & nd \\
\hline Thermomicrobia & $0.4^{\mathrm{b}} \pm>0.01$ & $0.5^{\mathrm{a}} \pm>0.01$ & $0.2^{\mathrm{c}} \pm>0.01$ & $0.2^{\mathrm{c}} \pm>0.01$ \\
\hline Planctomycetes & $0.8^{\mathrm{a}} \pm 0.1$ & $0.7^{\mathrm{a}} \pm 0.1$ & $0.3^{\mathrm{b}} \pm 0.1$ & $0.3^{\mathrm{b}} \pm 0.1$ \\
\hline Phycisphaerae & $>0.01 \pm>0.01$ & $>0.01 \pm>0.01$ & $>0.01 \pm>0.01$ & $>0.01 \pm>0.01$ \\
\hline Planctomycetia & $0.8^{\mathrm{a}} \pm 0.1$ & $0.7^{\mathrm{a}} \pm 0.1$ & $0.3^{\mathrm{b}} \pm 0.1$ & $0.3^{\mathrm{b}} \pm 0.1$ \\
\hline Verrucomicrobia & $0.6^{\mathrm{a}} \pm 0.1$ & $0.7^{\mathrm{a}} \pm 0.1$ & $0.2^{\mathrm{b}} \pm 0.1$ & $0.2^{\mathrm{b}} \pm>0.01$ \\
\hline Opitutae & $>0.01 \pm>0.01$ & nd & nd & nd \\
\hline Verrucomicrobiae & $0.6^{\mathrm{a}} \pm 0.1$ & $0.7^{\mathrm{a}} \pm 0.1$ & $0.2^{\mathrm{b}} \pm 0.1$ & $0.3^{\mathrm{b}} \pm>0.01$ \\
\hline Ignavibacteriae & $0.1^{\mathrm{a}} \pm>0.01$ & $0.2^{\mathrm{a}} \pm>0.01$ & $0.1^{\mathrm{b}} \pm>0.01$ & $0.1^{\mathrm{b}} \pm>0.01$ \\
\hline Unclassified Bacteria & $1.8^{\mathrm{a}} \pm 0.3$ & $2.1^{\mathrm{a}} \pm 0.4$ & $0.8^{\mathrm{b}} \pm 0.2$ & $0.9^{\mathrm{b}} \pm 0.1$ \\
\hline
\end{tabular}

Values are presented as mean relative abundance \pm standard error (SE) of phylogenetic groups at the phylum and class levels. Statistical significances between the treatments inferred by ANOVA with false discovery rate post-hoc multiple correction test (FDR, $p<0.05)$ are marked by lowercase letters. Nd stands for 'not detected'

between the treatments can be excluded (Figs. 4 and 5, Fig. S3). RU47 was significantly more abundant in rhizosphere of treatments with RU47 cells than in all other treatments, especially in comparison with HT-
RU47 (Fig. 5). This finding confirms the high rhizosphere competence of RU47 as already reported by Adesina et al. (2009) and Schreiter et al. (2014b). Both studies investigated the ability of RU47 to colonize the 
Fig. 5 Generalized heatmap of dominant responders in the rhizosphere of one optimally $\mathrm{P}$ fertilized, non-inoculation ( $\mathrm{P}$ fertilized) and three inoculation treatments using unselectively cultivated soil bacteria (bacterial mix), heat treated RU47 (HTRU47), or viable RU47 (RU47) cells of tomato plants 39 days after sowing. Only OTUs with relative abundance $>0.1 \%$ and significantly responding are displayed (nbGLM, likelihood ratio test, $p<0.05$ )

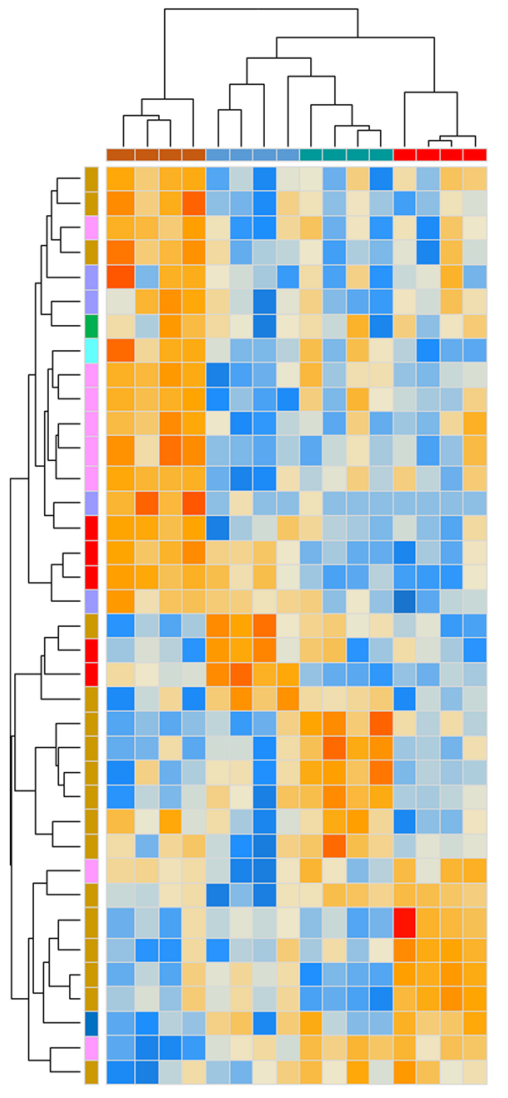

Center-scaled counts

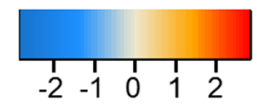

Gammaproteobacterium OTU709

Thermomonassp. Ms32

Lysobacteryangpyeongensis

Altererythrobacter OTU4403

Sphingopyxis sp. Aza22

Luteolibacter OTU4044

Achromobacter

Pedobacter 7A7

Dyadobacter beijingensis

Terrimonas_OTU70

Flavisolibacter OTU782

Flavisolibacter_SC-2_38

Azospirillum

Tumebacillus sp._23-2

Bacillus spp.

Clostridium rumen bactNC30

Sphingomonadaceae_OTU278

Lysobacter OTU379

Tumebacilluss_OTU723

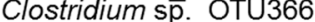

Pseudomonas resinovorans

Pseudomonas aeruginosa_OTU1360

Pseudomonas fluorescens OTU4419

Pseudomonas putida OTU4480

Pseudomonas aerugiñosa_OTU2209

Pseudomonas_OTU0

Pseudomonas-OTU4271

Terrimonas OTU296

Pseudomoñasfluorescens OTU2248

RU47_OTU4407

RU47-OTU4397

RU47-OTU620

RU47-OTU2283

Rubrobacter_OTU1

Parapedobacter OTU292

Luteimonas mephitis

Row legend

Alphaproteobacteria

Betaproteobacteria

Gammaproteobacteria

Bacteroidetes

Firmicutes

Actinobacteria

Verrucomicrobia

\section{Column legend}

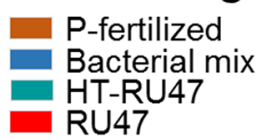

P-fertilized

Bacterial mix

RU47 rhizosphere of lettuce either in growth chambers or under field conditions. However, in these studies, cultivationdependent methods (i.e. selective plating/re-cultivating the inoculum) were used. The RU47 is a spontaneous rifampicin-resistant mutant; this makes sensitive and specific detection of RU47 in rhizosphere and bulk soil possible using selective plating. Unfortunately, selective plating was not used in the present experiment. Commercial as well as non-commercial PMB strains, including RU47, were originally isolated from indigenous microbial communities associated with soils and plants. In contrast to genetically modified strains, specific and sensitive monitoring of naturally occurring strains is more difficult. The literature, though sparse, suggests that survival of inoculants such as PMB is difficult to track and that the inoculants exhibit great temporal and spatial dependency. A temporal decrease in abundance has frequently been reported (Kim et al. 1997; Dey et al. 2004; Hameeda et al. 2008; Meyer et al. 2017). For instance, Meyer et al. (2017) documented a loss of more than $99 \%$ of the inoculated Pseudomonas protegens CHA0 cells within 40 days. Kim et al. (1997) determined that Enterobacter agglomerans found in the rhizosphere of non-inoculated tomato plants (35 days after sowing) corresponded to almost $50 \%$ of the abundance in the inoculation treatment.

Improved P supply

Data on effects of PMB addition on plant growth and $\mathrm{P}$ uptake are rare and somewhat inconsistent. However, 
Egamberdiyeva (2007) and Kumar et al. (2013) demonstrated improved $\mathrm{P}$ uptake in maize and mustard respectively due to addition of single PMB strains. Although not significant, these findings are consistent with the results of our study, which showed higher P accumulation in tomato plants inoculated with HT-RU47 and viable RU47 (Fig. 1). In evaluating plant P uptake, P tissue concentration is the meaningful value because differences resulting from variations in plant growth are excluded. Variations in plant growth may therefore explain the adequate $\mathrm{P}$ tissue concentration of $0.4 \%$ (Table S2) that was observed not only in the optimally P-fertilized treatment but also in the plants inoculated with a bacterial mix. In the bacterial mix treatment, the lowest amounts of available P in the soils (from small starter $\mathrm{P}$ fertilization at the beginning of the experiment) were taken up by the plants in comparison to the other treatments, and this $\mathrm{P}$ was not enough to maintain growth (Fig. 1). The previously incorporated $\mathrm{P}$ was concentrated in the small biomass, resulting in apparent adequate initial $\mathrm{P}$ tissue concentration of $0.4 \%$, but this was a concentration effect relative to low tissue biomass. As plants grew, the initially adsorbed $\mathrm{P}$ was no longer available, and these plants then exhibited $\mathrm{P}$ deprivation, as indicated by violet discoloration of leaves (Table 2 , Table S2). Plants inoculated with RU47 had a P tissue concentration of $0.2 \%$ (Table S2), which is in close agreement with the data reported by Kim et al. (1997) but may also indicate competition for available $\mathrm{P}$ between added bacteria and plant. This assumption is supported by the optimal $\mathrm{P}$ tissue concentration of $0.6 \%$ found in plants which were inoculated with HT-RU47 cells. In these plants competition was reduced, while highest $\mathrm{P}_{\text {mic }}$ values were determined in soil of the viable RU47 treatment, a condition in which competition between plants and bacteria is expected to be highest. An improved $\mathrm{P}$ supply by the addition of RU47 or HT-RU47 was also observed by a 2-fold higher $\mathrm{P}_{\mathrm{H} 2 \mathrm{O}}$ concentration compared to the bacterial mix treatment (Table 2). However, a fertilizing effect due to addition of HT-RU47 cells can be excluded since $\mathrm{N}$ and $\mathrm{P}$ concentrations in cell suspension $\left(\mathrm{OD}_{600}=1\right)$ were determined as 41.5 and $0.9 \mu \mathrm{g} \mathrm{mL}^{-1}$, respectively, corresponding to a total $\mathrm{N}$ and $\mathrm{P}$ addition of less than $0.6 \mathrm{mg} \mathrm{kg}^{-1}$ (data not shown). These values are negligible in comparison to the initial slight $\mathrm{P}$ fertilization $\left(50 \mathrm{mg} \mathrm{kg}^{-1}\right)$ and the optimal fertilized control $\left(200 \mathrm{mg} \mathrm{kg}^{-1}\right)$.
Improved P mobilization in soil

An improved $\mathrm{P}$ supply by $\mathrm{PMB}$, including some Pseudomonas strains, has been reported in several studies (for overviews, see Rodríguez and Fraga 1999; Khan et al. 2007; Harvey et al. 2009). For instance, Malboobi et al. (2009) documented effective mobilization of inorganic and organic phosphate compounds by Pseudomonas putida P13 in culture media. Similar findings were reported by Pastor et al. (2012). They observed growth stimulation of tomato seedlings by the addition of P. putida PCI2 and were able to identify this strain as positive for PA and highly effective for solubilizing Al- and Ca-bound phosphates. In our study, inoculations with RU47 resulted in increased alkaline phosphomonoesterase activity in the rhizosphere of tomato plants (Fig. 2a). Moreover, enzyme activity measured by zymography increased from 18 to 19 to $25-$ 26 days after sowing, likely due to increasing bacterial colonization and P depletion. In contrast, alkaline PA in the rhizosphere inoculated with HT-RU47 remained stable (Fig. 2a). These findings suggest increased $\mathrm{P}$ mineralization by microbial phosphatases produced by viable RU47. In general, zymography revealed similar activity levels for alkaline and acid PA, which is in accordance with Spohn et al. (2015). They determined the PA in the rhizosphere of barley grown under low and adequate $\mathrm{P}$ soil conditions and observed a similarity of approximately $90 \%$ between alkaline and acid PA. In contrast to the experiment of Spohn et al. (2015), we observed no distinct separation between roots and surrounding soil (Fig. S2) and also generally lower PA (Fig. $2 \mathrm{a}, \mathrm{b})$. This may be attributable to the comparatively fine roots of tomato plants as compared to barley. Lower enzyme activity levels in comparison to the values of Spohn et al. (2015) may have been due to the addition of quartz sand in the present experiment.

PA data determined by soil in situ zymography indicated the spatial and temporal distribution of enzyme activity in the rhizosphere (soil area) during different growth stages of the tomato plants. Enzyme analyses performed after final harvest enabled us to gain additional information about the potential PA in bulk soil (soil body) at a single time point. Measured highest alkaline and acid PA values in soil inoculated with RU47 after final harvest agreed with our soil zymography results (Table 2, Fig. 2a, b). In comparison to the bacterial mix treatment, alkaline PA increased by $16 \%$ (Table 2). These results are in agreement with those 
obtained by Kaur and Reddy (2014), who documented increases in alkaline PA of $31 \%$ due to the addition of Pseudomonas plecoglossicida in soil of wheat plants. These findings reinforce the evidence for improved $\mathrm{P}$ mineralization by the addition of RU47. Nevertheless, bulk soil inoculated with HT-RU47 cells also revealed increased PA (Table 2), despite the effectively killing of RU47 by HT and the denaturation of phosphatases. By taking into account that increased PA in HT-RU47 treatment was observed only once and perhaps temporary, this observation allows us to speculate that the addition of bacterial residues (HT-RU47 cells) and thus a supply of fresh organic matter (FOM) may enhanced growth and activity of previously of bacterial populations, especially Pseudomonads (Fig. 5), also known as the priming effect (Bingeman et al. 1953; Fontaine et al. 2003).

Interactions with indigenous soil microbes and hormone-derived effects

An initially conducted denaturing gradient gel electrophoresis (DGGE) analysis of 16S rRNA gene amplified from TC-DNA revealed no RU47-related band in the HT-RU47 treatment, but dominant bands which were absent or less intense in all other treatments (Fig. S4). Furthermore, high d-values (permutation test) indicating large differences were observed between the fingerprints of the HT-RU47 and viable RU47 (43.2), and between the bacterial mix and HT-RU47 (28.4; Table S3). This first indication of changed bacterial community composition, especially when HT-RU47 cells were added, was supported by the amplicon sequencing showing less present RU47-specific OTUs in HT-RU47 treatment, as well as the presence of 8 OTUs affiliated to other different Pseudomonas (Fig. 5). We assume, therefore, that inoculation of HT-RU47 cells, and thus the addition of FOM in the form of bacterial residues to soil, resulted in a priming effect that enhanced bacterial populations, especially belonging to Gammaproteobacteria (Fig. 5). This, in turn, resulted in the growth of bacterial populations responding to the $\mathrm{C}$ spike accompanied by increased microbial PA in bulk soil, resulting in the observed improved $\mathrm{P}$ supply for the tomato plants in this treatment (Table 2). This assumption is confirmed by data of RDA that revealed a highly positive correlation between HT-RU47 and the variables plant's P uptake and PA (Fig. 4). However, despite finding no strong evidence of enhancement in microbial $\mathrm{C}$ degradation via RDA, phylogenetic variations within the genus Pseudomonas dominating bacterial diversity in HTRU47 might have disguised a positive correlation between HT-RU47 and enzymes involved in the C cycle (Fig. 4, Fig. S3). On the other hand, RDA revealed positive correlations between the $\mathrm{P}$ fertilized treatment and the microbial biomass C:P ratio as well as activity of carbohydrate degrading enzymes (Fig. 4). Phylogenetic diversity of this treatment was mainly characterised by, inter alia, Bacteroidetes, Alpha- and Betaproteobacteria, which are identified to follow the copiotrophic nutritional strategy (Fierer et al. 2007; Fig. 5). Activities of carbohydrate degrading enzymes might explain the negative correlation between this treatment and soil's $\mathrm{pH}$, as higher $\mathrm{C}$ degradation activity may increase soil acidity via organic acid release (e.g. acetate; Fig. 4). The absence of positive correlation between P-fertilized and the PA is well explainable by soil's initially high $\mathrm{P}$ fertilization (Fig. 4). Although we found no significant effects on PLFA patterns, bulk soil inoculated with RU47 cells showed a minor increase in bacterial abundance, especially of gram $^{+}$bacteria (Table 2) likely indicating microbiome shift as a result of RU47 inoculation, a finding also reported by Schreiter et al. (2014a). Amplicon sequencing revealed strikingly different taxonomic affiliation of the dominant genera and showed that in the HT-RU47 treatments OTUs affiliated to Pseudomonas were dominant which were not detected in the other treatments and were clearly distinct from RU47 (Fig. 5). This Pseudomonas population might have contributed to the increased microbial PA and improved P supply determined in bulk soils of both RU47 treatments. An increase in abundance of indigenous PMB after the application of specific PMB strains has also been reported by Sundara et al. (2002) and Canbolat et al. (2006). Supporting this assumption, heatmap showed OTUs that seemed to have been facilitated by RU47 regardless of its viability, including Parapedobacter sp., Luteimonas mephitis, and Pseudomonas fluorescens, the latter, at least, include several well studied plant growth-promoting bacteria strains (e.g. McGrath et al. 1995; Park et al. 2015). To solve this open question, functional gene analyses of phosphomonoesterases could clarify identities of the main producers of different phosphomonoesterases and should be considered in future studies. Plant growth 
promotion can be strongly influenced by modulation of the phytohormone level of the plant. Several studies have shown that many soil bacteria, including Pseudomonas, are able to synthesize phytohormones or the enzyme 1-aminocyclopropane-1-carboxylate (ACC) deaminase, affecting the plant's hormonal balance and thus its growth and response to stress, ensuring the bacteria's supply of $\mathrm{C}$ resources from root exudation (for review see Tsavkelova et al. 2006; Glick 2012). Hence, the plant growth promotion observed in both RU47 treatments was likely due to a hormonemediated effect. Rajkumar and Freitas (2008) reported a strong effect of ACC deaminase production by P. jessenii M6; this was also detected for RU47 (Eltlbany et al., under review). But, due to enzyme inactivation in the HT-RU47 treatment, an ACC deaminase effect was negligible here. However, it is known that phytohormones such as auxins and cytokinins remain stable after heating to $121{ }^{\circ} \mathrm{C}$ (Murashige and Skoog 1962; Kumar 2009). Although, it is entirely possible that co-extracted thermally stable phytohormones produced by RU47 before they were killed were added through inoculation of HT-RU47 cells it is more likely that the addition of HT-RU47 cells promoted indigenous, phytohormones synthesizing soil microorganisms, including especially bacterial genus belonging to Pseudomonas as indicated by the amplicon sequencing analysis (Fig. 5; for review see Tsavkelova et al. 2006; Glick 2012). Taken together, the improved P supply in plants inoculated with HT-RU47 or viable RU47 may have been due to phytohormones, stimulating root growth and activity, and improving $\mathrm{P}$ acquisition in soil.

\section{Conclusion}

This study demonstrated that addition of RU47 improves the $\mathrm{P}$ supply and subsequent growth of tomato plants under P-limited growing conditions. Furthermore, it indicated enhanced production of alkaline phosphatase in the RU47 treatments. This is the first study to compare the effects of adding viable and dead RU47 cells to plants and soil. In both treatments higher P uptake and plant growth promotion were observed. The plant growth-promoting effect was likely caused by increased PA in the rhizosphere of tomato amended with viable RU47. In the HT-RU47 treatment, the bacterial populations which proliferated in response to the added resource may have contributed to improved P supply and growth promotion via other mechanisms. Thus, the use of RU47 offers a promising approach for more efficient $P$ fertilization in agriculture. In contrast to our hypothesis that the colonization of RU47 leads to spatially distinct zones of increased PA in the rhizosphere, no clear differences in rhizosphere and bulk soil were found. This was likely due to the fine roots of tomato plants and homogeneously distributed enzyme activity of the topsoil used in the treatments. We found no significant effects of RU47 on soil microbial community structure as determined by PLFAs, but we detected significant shifts in bacterial composition of the rhizosphere using $16 \mathrm{~S}$ amplicon sequencing. Our study shows that RU47 increases microbial PA in soil with low $\mathrm{P}$ availability and leads to growth promotion of tomato plants.

Acknowledgments This work was supported by the European Commission within the 7th Framework Programme | Grant Agmt. No. 312117 as part of the BIOFECTOR project. We thank the Department of Soil Ecology, University of Bayreuth, for providing the premises of the rhizobox experiment. We thank the Institute for Epidemiology and Pathogen Diagnostics, Julius Kühn-Institut, for providing the Pseudomonas sp. RU47 culture. We are very grateful to Søren Johannes Sørensen from the Section of Microbiology at the University of Copenhagen for providing the sequencing facilities. Furthermore, the support of Günter Neumann, Markus Weinmann, Kathleen Regan and Ilse-Marie Jungkurth is acknowledged.

Open Access This article is distributed under the terms of the Creative Commons Attribution 4.0 International License (http:// creativecommons.org/licenses/by/4.0/), which permits unrestricted use, distribution, and reproduction in any medium, provided you give appropriate credit to the original author(s) and the source, provide a link to the Creative Commons license, and indicate if changes were made.

\section{References}

Adesina MF, Lembke A, Costa R, Speksnijder A, Smalla K (2007) Screening of bacterial isolates from various European soils for in vitro antagonistic activity towards Rhizoctonia solani and Fusarium oxysporum: site-dependent composition and diversity revealed. Soil Biol Biochem 39:2818-2828. https://doi.org/10.1016/j.soilbio.2007.06.004

Adesina MF, Grosch R, Lembke A, Vatchev TD, Smalla K (2009) In vitro antagonists of Rhizoctonia solani tested on lettuce: rhizosphere competence, biocontrol efficiency and rhizosphere microbial community response. FEMS Microbiol Ecol 69:62-74. https://doi.org/10.1111/j.15746941.2009.00685.x 
Belimov AA, Kojemiakov AP, Chuvarliyeva CN (1995) Interaction between barley and mixed cultures of nitrogen fixing and phosphate-solubilizing bacteria. Plant Soil 173: 29-37. https://doi.org/10.1007/BF00155515

Bertani G (1951) Studies on lysogenesis I: the mode of phage liberation by lysogenic Escherichia coli1. J Bacteriol 62:293

Bingeman CW, Varner JE, Martin WP (1953) The effect of the addition of organic materials on the decomposition of an organic soil. Soil Sci Soc Am J 17:34-38. https://doi. org/10.2136/sssaj1953.03615995001700010008x

Bünemann EK, Steinebrunner F, Smithson PC, Frossard E, Oberson A (2004) Phosphorus dynamics in a highly weathered soil as revealed by isotopic labeling techniques. Soil Sci Soc Am J 68:1645-1655. https://doi.org/10.2136 /sssaj2004.1645

Canbolat MY, Bilen S, Çakmakçı R, Şahin F, Aydın A (2006) Effect of plant growth-promoting bacteria and soil compaction on barley seedling growth, nutrient uptake, soil properties and rhizosphere microflora. Biol Fertil Soils 42:350-357. https://doi.org/10.1007/s00374-005-0034-9

Chabot R, Antoun H, Cescas MP (1996) Growth promotion of maize and lettuce by phosphate-solubilizing Rhizobium leguminosarum biovar. Phaseoli. Plant Soil 184:311-321. https://doi.org/10.1007/BF00010460

Deubel A, Gransee A, Merbach W (2000) Transformation of organic rhizodepositions by rhizosphere bacteria and its influence on the availability of tertiary calcium phosphate. J Plant Nutr Soil Sci 163:387-392. https://doi.org/10.1002/1522-2624(200008)163:4<387 $:: A I D-J P L N 387>3.0 . C O ; 2-\mathrm{K}$

Dey R, Pal KK, Bhatt DM, Chauhan SM (2004) Growth promotion and yield enhancement of peanut (Arachis hypogaea L.) by application of plant growth-promoting rhizobacteria. Microbiol Res 159:371-394. https://doi.org/10.1016/j. micres.2004.08.004

Dick WA, Juma NG, Tabatabai MA (1983) Effects of soils on acid phosphatase and inorganic pyrophosphatase of corn roots. Soil Sci 136:19-25

Efron B (ed) (1982) The jackknife, the bootstrap and other resampling plans. Society of Industrial and Applied Mathematics, Philadelphia, pp 5-87. https://doi.org/10.1137 /1.9781611970319.fm

Egamberdiyeva D (2007) The effect of plant growth promoting bacteria on growth and nutrient uptake of maize in two different soils. Appl Soil Ecol 36:184-189. https://doi. org/10.1016/j.apsoil.2007.02.005

Fankem H, Ngo Nkot L, Deubel A, Quinn J, Merbach W, Etoa F, Nwaga D (2008) Solubilization of inorganic phosphates and plant growth promotion by strains of Pseudomonas fluorescens isolated from acidic soils of Cameroon. Afr J Microbiol Res 2:171-178

Felsenstein J (2003) Inferring Phylogenies, vol 664. Sinauer Associates, Sunderland

Fierer N, Bradford MA, Jackson RB (2007) Toward an ecological classification of soil bacteria. Ecology 88:1354-1364. https://doi.org/10.1890/05-1839

Fontaine S, Mariotti A, Abbadie L (2003) The priming effect of organic matter: a question of microbial competition? Soil Biol Biochem 35:837-843. https://doi.org/10.1016/S00380717(03)00123-8
Frossard E, Condron LM, Oberson A, Sinaj S, Fardeau JC (2000) Processes governing phosphorus availability in temperate soils. J Environ Qual 29:15-23. https://doi.org/10.2134 /jeq2000.00472425002900010003x

Frostegård Å, Bååth E (1996) The use of phospholipid fatty acid analysis to estimate bacterial and fungal biomass in soil. Biol Fertil Soils 22:59-65. https://doi.org/10.1007/BF00384433

Frostegård Å, Tunlid A, Bååth E (1991) Microbial biomass measured as total lipid phosphate in soils of different organic content. J Microbiol Methods 14:151-163. https://doi. org/10.1016/0167-7012(91)90018-L

Glick BR (2012) Plant growth-promoting bacteria: mechanisms and applications. Scientifica 63401:15. https://doi. org/10.6064/2012/963401

Hameeda B, Harini G, Rupela OP, Wani SP, Reddy G (2008) Growth promotion of maize by phosphate-solubilizing bacteria isolated from composts and macrofauna. Microbiol Res 163:234-242. https://doi.org/10.1016/j.micres.2006.05.009

Harvey PR, Warren RA, Wakelin S (2009) Potential to improve root access to phosphorus: the role of non-symbiotic microbial inoculants in the rhizosphere. Crop Pasture Sci 60:144 151. https://doi.org/10.1071/CP08084

Heuer H, Krsek M, Baker P, Smalla K, Wellington EMH (1997) Analysis of actinomycete communities by specific amplification of genes encoding 16S rRNA and gel electrophoretic separation in denaturing gradients. Appl Environ Microbiol 63:3233-3241

Heuer H, Wieland G, Schönfeld J, Schönwälder A, Gomes NCM, Smalla K (2001) Bacterial community profiling using DGGE or TGGE analysis. In: Rouchelle P (ed) Environmental molecular microbiology: protocols and applications. Horizon Scientific Press, Wymondham, pp 177-190

Hinsinger P (2001) Bioavailability of soil inorganic P in the rhizosphere as affected by root-induced chemical changes: a review. Plant Soil 237:173-195. https://doi.org/10.1023 /A:1013351617532

Hofmann K, Heuck C, Spohn M (2016) Phosphorus resorption by young beech trees and soil phosphatase activity as dependent on phosphorus availability. Oecologia 181:369-379. https://doi.org/10.1007/s00442-016-3581-x

Jacquiod S, Stenbæk J, Santos SS, Winding A, Sørensen SJ, Priemé A (2016) Metagenomes provide valuable comparative information on soil microeukaryotes. Res Microbiol 167: 436-450. https://doi.org/10.1016/j.resmic.2016.03.003

Jacquiod S, Brejnrod A, Morberg SM, Abu Al-Soud W, Sørensen SJ, Riber L (2017) Deciphering conjugative plasmid permissiveness in wastewater microbiomes. Mol Ecol 26:35563571. https://doi.org/10.1111/mec. 14138

Joergensen RG (1996) The fumigation-extraction method to estimate soil microbial biomass: calibration of the $\mathrm{k} E C$ value. Soil Biol Biochem 28:25-31. https://doi.org/10.1016/00380717(95)00102-6

Jones DL, Oburger E (2011) Solubilization of phosphorus by soil microorganisms. In: Bünemann EK, Oberson A, Frossard E, eds Phosphorus in action. Springer, Berlin, 169-198

Jones DL, Darrah PR (1994) Role of root derived organic acids in the mobilization of nutrients from the rhizosphere. Plant Soil 166:247-257. https://doi.org/10.1007/BF00008338

Jukes TH, Cantor CR (1969) Evolution of protein molecules. In: Munro HN (ed) Mammalian Protein Metabolism. Academic Press, New York, pp 21-132 
Juma NG, Tabatabai MA (1988) Hydrolysis of organic phosphates by corn and soybean roots. Plant Soil 107:31-38. https://doi. org/10.1007/BF02371541

Kalra YP, Maynard DG, Radford FG (1989) Microwave digestion of tree foliage for multi-element analysis. Can J For Res 19: 981-985. https://doi.org/10.1139/x89-150

Kandeler E, Mosier AR, Morgan JA, Milchunas DG, King JY, Rudolph S, Tscherko D (2008) Transient elevation of carbon dioxide modifies the microbial community composition in a semi-arid grassland. Soil Biol Biochem 40:162-171. https://doi.org/10.1016/j.soilbio.2007.07.018

Kaur G, Reddy MS (2014) Influence of P-solubilizing bacteria on crop yield and soil fertility at multilocational sites. Eur J Soil Biol 61:35-40. https://doi.org/10.1016/j.ejsobi.2013.12.009

Khan MS, Zaidi A, Wani PA (2007) Role of phosphatesolubilizing microorganisms in sustainable agriculture - a review. Agron Sustain Dev 27:29-43. https://doi. org/10.1051/agro:2006011

Khan AA, Jilani G, Akhtar MS, Naqvi SMS, Rasheed M (2009) Phosphorus solubilizing bacteria: occurrence, mechanisms and their role in crop production. J Agric Biol Sci 1:48-58

Kim KY, Jordan D, McDonald GA (1997) Effect of phosphatesolubilizing bacteria and vesicular-arbuscular mycorrhizae on tomato growth and soil microbial activity. Biol Fertil Soils 26:79-87. https://doi.org/10.1007/s003740050347

King EO, Ward MK, Raney DE (1954) Two simple media for the demonstration of pyocyanin and fluorescin. J Lab Clin Med 44:301-307

Kouno K, Wu J, Brookes PC (2002) Turnover of biomass C and P in soil following incorporation of glucose or ryegrass. Soil Biol Biochem 34:617-622. https://doi.org/10.1016/S00380717(01)00218-8

Kpomblekou-a K, Tabatabai MA (1994) Effect of organic acids on release of phosphorus from phosphate rocks1. Soil Sci 158: 442-453

Kropf S, Heuer H, Grüning M, Smalla K (2004) Significance test for comparing complex microbial community fingerprints using pairwise similarity measures. J Microbiol Methods 57:187-195. https://doi.org/10.1016/j.mimet.2004.01.002

Kumar S, Singh MP (2009) Principles and methodology in plant tissue culture. In: Kumar S, Singh MP, eds (2009) Plant tissue culture. Balaji Offset, New Delhi, 34

Kumar V, Singh P, Jorquera MA, Sangwan P, Kumar P, Verma AK, Agrawal S (2013) Isolation of phytase-producing bacteria from Himalayan soils and their effect on growth and phosphorus uptake of Indian mustard (Brassica juncea). World J Microbiol Biotechnol 29:1361-1369. https://doi. org/10.1007/s11274-013-1299-Z

Kumar S, Stecher G, Tamura K (2016) MEGA7: molecular evolutionary genetics analysis version 7.0 for bigger data sets. Mol Biol Evol 33:1870-1874. https://doi.org/10.1093 /molbev/msw054

Lennox ES (1955) Transduction of linked genetic characters of the host by bacteriophage P1. Virology 1:190-206. https://doi. org/10.1016/0042-6822(55)90016-7

Mackie KA, Marhan S, Ditterich F, Schmidt HP, Kandeler E (2015) The effects of biochar and compost amendments on copper immobilization and soil microorganisms in a temperate vineyard. Agric Ecosyst Environ 201:58-69. https://doi. org/10.1016/j.agee.2014.12.001
Malboobi MA, Owlia P, Behbahani M, Sarokhani E, Moradi S, Yakhchali B, Kambiz DA, Heravi M, Heravi KM (2009) Solubilization of organic and inorganic phosphates by three highly efficient soil bacterial isolates. World J Microbiol Biotechnol 25:1471-1477. https://doi.org/10.1007/s11274009-0037-z

Marschner P, Crowley D, Rengel Z (2011) Rhizosphere interactions between microorganisms and plants govern iron and phosphorus acquisition along the root axis-model and research methods. Soil Biol Biochem 43:883-894. https://doi. org/10.1016/j.soilbio.2011.01.005

Marx MC, Wood M, Jarvis SC (2001) A microplate fluorimetric assay for the study of enzyme diversity in soils. Soil Biol Biochem 33:1633-1640. https://doi.org/10.1016/S00380717(01)00079-7

McGrath JW, Wisdom GB, McMullan G, Lrakin MJ, Quinn JP (1995) The purification and properties of phosphonoacetate hydrolase, a novel carbon-phosphorus bond-cleaving enzyme from Pseudomonas fluorescens 23F. Eur J Biochem 234:225230. https://doi.org/10.1111/j.1432-1033.1995.225_c.x

McMurdie PJ, Holmes S (2014) Waste not, want not: why rarefying microbiome data is inadmissible. PLoS Comput Biol 10: e1003531. https://doi.org/10.1371/journal.pcbi.1003531

Meyer G, Bünemann EK, Frossard E, Maurhofer M, Mäder P, Oberson A (2017) Gross phosphorus fluxes in a calcareous soil inoculated with Pseudomonas protegens CHA0 revealed by $33 \mathrm{P}$ isotopic dilution. Soil Biol Biochem 104:81-94. https://doi.org/10.1016/j.soilbio.2016.10.001

Murashige T, Skoog F (1962) A revised medium for rapid growth and bio assays with tobacco tissue cultures. Physiol Plant 15:473-497. https://doi.org/10.1111 /j.1399-3054.1962.tb08052.x

Murphy J, Riley JP (1962) A modified single solution method for the determination of phosphate in natural waters. Anal Chim Acta 27:31-36. https://doi.org/10.1016/S0003-2670(00 )88444-5

Nannipieri P, Giagnoni L, Landi L, Renella G (2011) Role of phosphatase enzymes in soil. In: Bünemann EK, Oberson A, Frossard E, eds (2011) Phosphorus in action. Springer, Berlin, 215-243

Nei M, Kumar S (2000) Molecular evolution and phylogenetics. Oxford University Press, New York, pp 3-285

Niemi RM, Vepsäläinen M (2005) Stability of the fluorogenic enzyme substrates and $\mathrm{pH}$ optima of enzyme activities in different Finnish soils. J Microbiol Methods 60:195-205. https://doi.org/10.1016/j.mimet.2004.09.010

Nunes I, Jacquiod S, Brejnrod A, Holm PE, Johansen A, Brandt KK, Priemé A, Sørensen SJ (2016) Coping with copper: legacy effect of copper on potential activity of soil bacteria following a century of exposure. FEMS Microbiol Ecol 92: 175. https://doi.org/10.1093/femsec/fiw175

Oehl F, Sieverding E, Mäder P, Dubois D, Ineichen K, Boller T, Wiemken A (2004) Impact of long-term conventional and organic farming on the diversity of arbuscular mycorrhizal fungi. Oecologia 138:574-583. https://doi.org/10.1007 /s00442-003-1458-2

Park YS, Dutta S, Ann M, Raaijmakers JM, Park K (2015) Promotion of plant growth by Pseudomonas fluorescens strain SS101 via novel volatile organic compounds. Biochem Biophys Res Commun 461:361-365. https://doi. org/10.1016/j.bbrc.2015.04.039 
Pastor N, Carlier E, Andrés J, Rosas SB, Rovera M (2012) Characterization of rhizosphere bacteria for control of phytopathogenic fungi of tomato. J Environ Manag 95:332-337. https://doi.org/10.1016/j.jenvman.2011.03.037

Poll C, Ingwersen J, Stemmer M, Gerzabek MH, Kandeler E (2006) Mechanisms of solute transport affect small-scale abundance and function of soil microorganisms in the detritusphere. Eur J Soil Sci 57:583-595. https://doi. org/10.1111/j.1365-2389.2006.00835.x

Rajkumar M, Freitas H (2008) Influence of metal resistant-plant growth-promoting bacteria on the growth of Ricinus communis in soil contaminated with heavy metals. Chemosphere 71:834-842. https://doi.org/10.1016/j. chemosphere.2007.11.038

Richardson AE, Barea JM, McNeill AM, Prigent-Combaret C (2009) Acquisition of phosphorus and nitrogen in the rhizosphere and plant growth promotion by microorganisms. Plant Soil 321:305-339. https://doi.org/10.1007/s11104-0099895-2

Rodríguez H, Fraga R (1999) Phosphate solubilizing bacteria and their role in plant growth promotion. Biotechnol Adv 17: 319-339. https://doi.org/10.1016/S0734-9750(99)00014-2

Ron Vaz MD, Edwards AC, Shand CA, Cresser MS (1993) Phosphorus fractions in soil solution: influence of soil acidity and fertiliser additions. Plant Soil 148:175-183. https://doi. org/10.1007/BF00012855

Saitou N, Nei M (1987) The neighbor-joining method: a new method for reconstructing phylogenetic trees. Mol Biol Evol 4:406-425. https://doi.org/10.1093/oxfordjournals. molbev.a040454

Schöler A, Jacquiod S, Vestergaard G, Schulz S, Schloter M (2017) Analysis of soil microbial communities based on amplicon sequencing of marker genes. Biol Fertil Soils 53:485-489. https://doi.org/10.1007/s00374017-1205-1

Schreiter S, Ding GC, Grosch R, Kropf S, Antweiler K, Smalla K (2014a) Soil type-dependent effects of a potential biocontrol inoculant on indigenous bacterial communities in the rhizosphere of field-grown lettuce. FEMS Microbiol Ecol 90:718730. https://doi.org/10.1111/1574-6941.12430

Schreiter S, Sandmann M, Smalla K, Grosch R (2014b) Soil type dependent rhizosphere competence and biocontrol of two bacterial inoculant strains and their effects on the rhizosphere microbial community of field-grown lettuce. PLoS One 9(8): e103726. https://doi.org/10.1371/journal.pone.0103726

Shand CA, Macklon AE, Edwards AC, Smith S (1994) Inorganic and organic $\mathrm{P}$ in soil solutions from three upland soils. Plant Soil 160:161-170. https://doi.org/10.1007/BF00010142

Spohn M, Kuzyakov Y (2013) Distribution of microbial-and rootderived phosphatase activities in the rhizosphere depending on $\mathrm{P}$ availability and $\mathrm{C}$ allocation-coupling soil zymography with 14 C imaging. Soil Biol Biochem 67:106-113. https://doi.org/10.1016/j.soilbio.2013.08.015

Spohn M, Kuzyakov Y (2014) Spatial and temporal dynamics of hotspots of enzyme activity in soil as affected by living and dead roots - a soil zymography analysis. Plant Soil 379:6777. https://doi.org/10.1007/s11104-014-2041-9
Spohn M, Carminati A, Kuzyakov Y (2013) Soil zymography-a novel in situ method for mapping distribution of enzyme activity in soil. Soil Biol Biochem 58:275-280. https://doi. org/10.1016/j.soilbio.2012.12.004

Spohn M, Treichel NS, Cormann M, Schloter M, Fischer D (2015) Distribution of phosphatase activity and various bacterial phyla in the rhizosphere of Hordeum vulgare L. depending on P availability. Soil Biol Biochem 89:44-51. https://doi. org/10.1016/j.soilbio.2015.06.018

Sundara B, Natarajan V, Hari K (2002) Influence of phosphorus solubilizing bacteria on the changes in soil available phosphorus and sugarcane and sugar yields. Field Crop Res 77: 43-49. https://doi.org/10.1016/S0378-4290(02)00048-5

Tabatabai MA (1994) Soil enzymes. In: Weaver RW, Angle JS, Bottomley PS, eds, (1994) Methods of soil analysis, part 2, Microbiological and Biochemical Properties. Soil Sci Soc Am, Madison, 775-833

Tarafdar JC, Claassen N (1988) Organic phosphorus compounds as a phosphorus source for higher plants through the activity of phosphatases produced by plant roots and microorganisms. Biol Fertil Soils 5:308-312. https://doi.org/10.1007 /BF00262137

Tarafdar JC, Yadav RS, Meena SC (2001) Comparative efficiency of acid phosphatase originated from plant and fungal sources. J Plant Nutr 164:279-282. https://doi.org/10.1002/15222624(200106)164:3<279::AID-JPLN279>3.0.CO;2-L

Thorsen J, Brejnrod A, Mortensen M, Rasmussen MA, Stokholm J, Al-Soud WA, Sørensen S, Bisgaard H, Waage J (2016) Large-scale benchmarking reveals false discoveries and count transformation sensitivity in 16S rRNA gene amplicon data analysis methods used in microbiome studies. Microbiome 4:1-14. https://doi.org/10.1186/s40168-0160208-8

Tsavkelova EA, Klimova SY, Cherdyntseva TA, Netrusov AI (2006) Microbial producers of plant growth stimulators and their practical use: a review. Appl Biochem Microbiol 42:117-126. https://doi.org/10.1134 /S0003683806020013

Vance ED, Brookes PC, Jenkinson DS (1987) An extraction method for measuring soil microbial biomass C. Soil Biol Biochem 19:703-707. https://doi.org/10.1016/0038-0717(87 )90052-6

Wang Y, Naumann U, Wright ST, Warton DI (2012) Mvabund - an $\mathrm{R}$ package for model-based analysis of multivariate abundance data. Methods Ecol Evol 3:471-474. https://doi. org/10.1111/j.2041-210X.2012.00190.x

Weinert N, Meincke R, Gottwald C, Heuer H, Gomes NC, Schloter M, Berg G, Smalla K (2009) Rhizosphere communities of genetically modified zeaxanthinaccumulating potato plants and their parent cultivar differ less than those of different potato cultivars. Appl Environ Microbiol 75:3859-3865. https://doi. org/10.1128/AEM.00414-09

Xue QY, Ding GC, Li SM, Yang Y, Lan CZ, Guo JH, Smalla K (2013) Rhizocompetence and antagonistic activity towards genetically diverse Ralstonia solanacearum strains - an improved strategy for selecting biocontrol agents. Appl 
Microbiol Biotechnol 97:1361-1371. https://doi.org/10.1007 /s00253-012-4021-4

Zaidi A, Khan MS, Amil MD (2003) Interactive effect of rhizotrophic microorganisms on yield and nutrient uptake of chickpea (Cicer arietinum L.) Eur J Agron 19:15-21. https://oi.org/10.1016/s1161-0301(02)00015-1

Zelles L (1999) Fatty acid patterns of phospholipids and lipopolysaccharides in the characterisation of microbial communities in soil. A review. Biol Fertil Soils 29:111-129. https://oi. org/10.1007/s003740050533

Zhang L, Xu M, Liu Y, Zhang F, Hodge A, Feng G (2016) Carbon and phosphorus exchange may enable cooperation between an arbuscular mycorrhizal fungus and a phosphatesolubilizing bacterium. New Phytol 210:1022-1032. https://doi.org/10.1111/nph.13838 